\title{
Environmental performance policy indicators for the public sector: The case of the defence sector
}

\author{
Tomás B. Ramos ${ }^{\mathrm{a}, *}$, Inês Alves ${ }^{\mathrm{a}}$, Rui Subtil ${ }^{\mathrm{a}}$, João Joanaz de Melo ${ }^{\mathrm{b}}$ \\ ${ }^{\mathrm{a}}$ Faculty of Marine and Environmental Sciences, University of the Algarve, Campus de Gambelas, 8000-117 Faro, Portugal \\ ${ }^{\mathrm{b}}$ Department of Environmental Sciences and Engineering, Faculty of Sciences and Technology, New University of Lisbon, 2829-516 Caparica, Portugal
}

Received 20 September 2004; received in revised form 27 December 2005; accepted 29 December 2005

Available online 30 March 2006

\begin{abstract}
The development of environmental performance policy indicators for public services, and in particular for the defence sector, is an emerging issue. Despite a number of recent initiatives there has been little work done in this area, since the other sectors usually focused on are agriculture, transport, industry, tourism and energy. This type of tool can be an important component for environmental performance evaluation at policy level, when integrated in the general performance assessment system of public missions and activities. The main objective of this research was to develop environmental performance policy indicators for the public sector, specifically applied to the defence sector. Previous research included an assessment of the environmental profile, through the evaluation of how environmental management practices have been adopted in this sector and an assessment of environmental aspects and impacts. This paper builds upon that previous research, developing an indicator framework - SEPI-supported by the selection and construction of environmental performance indicators. Another aim is to discuss how the current environmental indicator framework can be integrated into overall performance management. The Portuguese defence sector is presented and the usefulness of this methodology demonstrated. Feasibility and relevancy criteria are applied to evaluate the set of indicators proposed, allowing indicators to be scored and indicators for the policy level to be obtained.
\end{abstract}

(C) 2006 Elsevier Ltd. All rights reserved.

Keywords: Public services; Environmental performance policy indicators; Defence sector

\section{Introduction}

There are significant differences between public sector organizations and the private sector, particularly at organizational and functional levels, with their specific policies, goals, objectives, targets, products and services. Public organizations must provide responses to the needs of society that are not covered by the private sector. As stated by Boland and Fowler (2000), in the public service there is no profit maximization focus, little potential for income generation and generally no bottom line against which financial performance can ultimately be measured. The majority of public organizations still generate most of

\footnotetext{
*Corresponding author. Tel.: + $351289800900 \times 7235$; fax: +351289818353 .

E-mail address: tramos@ualg.pt (T.B. Ramos).
}

their income from the state and have to account to several stakeholders.

Within the public sector there are several types of public organization such as: central and local government departments, agencies, trading funds and public corporations. Public sector organizations pursue political and social goals rather than simple commercial objectives. In the private sector, there are sole traders, partnerships, cooperatives and private and public limited companies. There are also hybrid organizations such as jointly owned enterprises where the government retains a share of ownership. According to Carter et al. (1992) it is surely better to dispense with the public/private dichotomy and regard ownership as a continuum ranging from the pure government department to the individual entrepreneur. Much performance assessment transcends the public/ private distinction and reflects characteristics which cut across this particular divide. 
Many public organizations produce services instead of products. The greatest experience with environmental management tools has been in business, and especially industry. Environmental management tools have been most often applied to manufacturing industries and tangible products. Beyond the traditional manufacturing sector, there is the need to go further and address their application to services, an underdeveloped and underresearched area of corporate environmental management (Welford et al., 1998). The typical differences stated in the work mentioned, between manufacturing industry and the service industry, can also be used to characterize public services, namely: (i) services are intangible (whereas manufactured goods are concrete); (ii) most services consist of acts and interaction; and (iii) the production and consumption of a service cannot always be kept apart. The particular case of the defence sector is characterized by its complexity, with its numerous personnel and many facilities and activities with, in turn, their numerous products and services. The different branches, i.e. the navy, army and air force, and the entire administrative sector carry out their missions. The main task of a country's armed forces is to defend and protect its sovereignty and interests. Due to the nature of its missions and activities, defence has an important social role and also has great potential to harm or benefit the environment in a highly visible manner. Compared to other government domains, defence services potentially have more significant environmental impacts than other public institutions.

The integration of environmental and sustainable development considerations into policy sectors and economic activities is one of most challenging targets at an international level. As stated by Hertin et al. (2001), in already difficult and contested areas of policy there is a risk that environmental and sustainable development is sidelined as a worthy, but intractable objective. When public policy needs to be increasingly flexible, responsive and cooperative, integration needs to be achieved by efficiency. Policy indicators are one possible way of ensuring that sustainability issues are being consistently and transparently considered in public policy. Indicators provide performance measurement, reporting and communication to stakeholders. Providing a coherent common framework for sector-environment integration indicators is a European goal and is becoming a reality in several sectors, such as transport, enterprise and agriculture. Despite their social, environmental and economic importance, the public sector overall and defence are often omitted in sectorenvironment integration approaches and studies.

There are many different kinds of frameworks for evaluating environmental and sustainability performance. Examples are the work carried out by Global Reporting Initiative (GRI) (2002), Melo and Pegado (2002), Tyteca et al. (2002), Dias-Sardinha and Reijnders (2001), Wehrmeyer et al. (2001), Bennett and James (1999b), Young and Welford (1998), Epstein and Young (1998), Johnson (1998), Ditz and Ranganathan (1997) and Azzone et al.
(1996), with particular focus on the organization level (profit or not-for-profit, private or public); at the sector level, Berkhout et al. (2001) for industry, United States Environmental Protection Agency (USEPA) (1999) for transport, and EEA (2000b) for various sectors (agriculture, transport, industry, energy and households) also developed performance frameworks. Despite the diversity of methods and tools for measuring environmental performance, indicators almost always play a central role. To assure that environmental performance indicators (EPIs) serve the purpose for which they are intended and to control the way they are specifically selected and developed, it is important to organize them into a framework. These frameworks can just focus on indicators or be integrated into broader performance assessment approaches, as happens with some of those mentioned above. Such diversity in environmental indicator frameworks, as shown by Hodge (1997) and Ramos et al. (2004c), is leading to increased difficulty in comparing organizations, sectors and countries and is contributing to a rather confusing and not very well established terminology, in contrast to the case with financial performance.

In addition, various authors make a contribution to defining the state of the art in EPIs for organizations, in particular at company level (e.g. Olsthoorn et al., 2001; Johnston and Smith, 2001; Bennett and James, 1999a; Ranganathan, 1998; Young and Welford, 1998; Callens and Tyteca, 1995; Tyteca, 1996; and Young, 1996), which shows the important progress achieved. The development of EPIs has evolved from pressure indicators, reporting on physical amounts based on inputs/outputs (e.g. air emissions, waste production or energy use), to the inclusion of the state of the environment and environmental impacts, as reported by Johnston and Smith (2001) and Olsthoorn et al. (2001). The drive to measure corporate environmental performance is the product of several factors, in particular compliance with legislation, image and reputation enhancement and stakeholder pressure, among others. Despite the different scope, the major driving forces for business are applicable to public sector organizations, with some exceptions such as market strategy or shareholder pressure.

Although the measurement of performance in the public sector is relatively new, an important amount of literature on performance management has developed since the late 1970s (Boland and Fowler, 2000). Public sector environmental performance integrated into overall performance management is substantially new, with little literature available.

The concept of sectoral environmental performance policy indicators (EPPIS) or environmental headline indicators, as used throughout this work, includes the evaluation of the environmental performance of public sector policies and activities in the context of overall performance management, providing particularly useful information for the top decision-makers and the general public. This kind of information could provide support to make evaluations 
among similar public sector areas, at a national or international level. These environmental indicators represent highly aggregated information which should be used like socio-economic indicators, gross domestic product (GDP), the inflation rate or the unemployment rate. For sectoral purposes headline indicators can be decomposed. Therefore, sector-specific indicators have to be added, since such aggregated information may not be sufficiently comprehensive for policy analysis and management (European Environment Agency (EEA), 1999).

The main objective of this research was to present a conceptual indicator framework and a set of EPPIs for the Portuguese defence sector. The main purpose of these indicators is to evaluate sectoral environmental performance, including the results of public policies and strategies, mandatory regulations and voluntary practices or standards. This study aims to contribute to the ongoing debate about indicator frameworks for sector-environment integration. Previous research includes an assessment of the environmental profile, through the evaluation of how environmental management practices have been adopted in the sector and an assessment of the main military activities (Ramos and Melo, 2005, 2006). It also includes an assessment of environmental aspects and impacts (Ramos et al., 2004a). This work builds upon that previous research, developing an indicator framework supported by the selection and construction of EPIs. Another aim is to discuss how current environmental indicator frameworks can be integrated into overall performance management. The indicators obtained should give the comprehensive support necessary to drive sectoral environmental performance evaluation.

\section{Overview of the experience with environmental indicators in the public and defence sectors}

Despite several initiatives on sector-environment integration indicators (e.g. Hertin et al., 2001; European Environment Agency (EEA), 2000a, b; Organization for Economic Co-operation and Development (OECD), 1999; USEPA, 1999), centered on pressure indicators, there are relatively few programmes of EPIs applied to the public sector overall or to the defence sector in particular. This is emphasized by a general dearth of scientific literature in this domain.

Nevertheless, some initiatives are presented here as examples of the ongoing work that is being carried out around the world. Tables 1 and 2 present an overview of environmental indicator systems applied to the public and defence sectors, respectively. The tables are based on chronological development and coverage: (i) the indicator framework; (ii) the indicators' primary objective; (iii) the number of indicators; (iv) the assessment target that they focus on (only for the defence sector).

The indicator initiatives in the public sector demonstrate that this domain is quite new around the world, despite several important examples, namely in the United King- dom and Canada. Environmental performance measurement is just one component of the strategies for greening government or sustainable development in government operations and the public sector overall. In the systems presented the number of EPIs range from 5 to 82, showing the great diversity of objectives and approaches and the generally poor methodological consensus in this emergent domain.

As with the public sector overall, defence indicator systems show a significant range of diversity, with the number of environmental indicators ranging from 2 to 60 . They are supported by different methodological frameworks, namely the Balanced Scorecard, ISO 14031, Pressure-State-Response and Leading-Lagging. Though some examples of environmental indicators are integrated in a broader approach to performance management for defence services (including social, environmental, economic/financial performance aspects), the majority are isolated environmental performance frameworks. Most of the examples presented show that sectoral environmental performance evaluation, measurement and reporting are the main objectives. Much of the work carried out does not use a well defined indicator framework with different categories, but rather just develops an ad hoc list of indicators without any particular methodological procedure.

\section{Development of the conceptual framework}

The development of EPIs for the defence sector faces additional problems and challenges. Defence activities cut across many sectors, e.g. transport, energy, industry and agriculture, among others, and lead to environmental interaction that reflects these links. Furthermore, the organizational complexity and the large dimension (area of land, personnel, equipment and infrastructure) of this sector are also important considerations to take into account. Due to these characteristics, establishing what to evaluate is one of the main tasks. It is very important to ascertain what environmental impacts can be assigned to defence organizations, defining the borders of the sector's environmental influence. It is necessary to clarify these limits to avoid double accounting between different economic sectors. Evaluating the integration of environmental issues into sector policies, including management practices, is also a hard task. As stressed by Carter et al. (1992), it is a recognized problem that the outcome of a specific policy measure is almost impossible to evaluate.

Despite the proliferation of environmental indicator frameworks, most of these frameworks have similar characteristics. However, it is hard to imagine that one standard indicator framework will be used by all the users that share the same objectives. Obtaining consensus and commitment from all the involved parties is a very difficult process. There are many different perspectives and realities, offering arguments to support specific indicator frameworks. On the other hand, a single framework is probably 
Table 1

Environmental indicator initiatives in the Public Sector

\begin{tabular}{|c|c|c|c|}
\hline Author/year & Framework name: indicator categories & Primary objectives/comments & $\begin{array}{l}\text { Number of } \\
\text { indicators* }\end{array}$ \\
\hline
\end{tabular}

\section{United States}

Environmental Protection

Agency (1996)

United Kingdom

Government (1997)

\section{PMSGO (1999)}

Government of Canada (2000)

Mohninger

(1999a,b,2000)
Compliance indicators

To assess environmental compliance at federal facilities. Standard indicators measure changes in compliance for the various programs in the same way the consumer price index measures changes in the rate of inflation relative to a given base year. Compliance indicators are intended to measure the level of relatively serious non-compliance at major federal facilities.

The initiative was created in 1997. The Greening Government initiative therefore represents an attempt to mainstream the environment across the entire work of government, incorporating environmental objectives in operational aspects of departmental performance but also greening the fundamental objectives of departments by ensuring that full weight is given to environmental impacts in policy appraisal and development. Its objective is to contribute to the government's annual report on sustainable development, including indicators on green government operations.

To assist Canadian federal departments/agencies in proposed field testing measures by providing details on their definition and guidance on their calculation. It is intended to complement the generic guidelines for planning and implementing the environmental performance measures contained in ISO 14031. The starting point for establishing environmental performance measures for the operations of federal departments is the environmental goals that departments/agencies have set in their sustainable development strategies (SDS) (e.g.Environment Canada, 1997).

Sustainable development in government operations: a coordinated approach

Environmental performance indicators: Internal performanceDirect effects-Environmental quality
Government of Canada (2002)
Environmental performance measures: Environmental load-

Coast load-

Efficiency measure-Activity—Proportion
Outlines a part of the government-wide effort to set common directions for the SDS. Is intended to promote green government and recommend best practices. Proposes a toolbox of collaboratively developed performance measures for seven priority areas and offers a sample set of concrete targets.

To develop baseline measurements and track progress in the area of environmental stewardship within Government of Jamaica ministries. Examines methods of measuring and monitoring the success of water, energy conservation and green purchasing programmes. To develop a baseline, set realistic targets and track whether these targets are being achieved. Internal performance indicators are a measurement of activities implemented by an organization in order to reduce its environmental impacts. Direct effect indicators measure the direct outcome of an organization's environmental activities and programmes (e.g. estimating the number of trees saved as a result of purchasing green paper). Environmental quality indicators are measures of the effects on the environment of an organization's environmental activities and programmes.

To provide environmental performance measures within the scope of Greening Government reporting guidelines. To help departments and agencies measure their progress in the eight priority areas identified (Government of Canada, 2000), namely: Energy Efficiency, Human Resources Managements, Land Use Management, Procurement, Vehicle Fleet Management, Waste Management, Water

Conservation, Wastewater Management and
5

Not available 
Table 1 (continued)

\begin{tabular}{|c|c|c|c|}
\hline Author/year & Framework name: indicator categories & Primary objectives/comments & $\begin{array}{l}\text { Number of } \\
\text { indicators* }\end{array}$ \\
\hline $\begin{array}{l}\text { United Kingdom } \\
\text { Government (2002) }\end{array}$ & $\begin{array}{l}\text { Framework for sustainable development on the } \\
\text { government estate }\end{array}$ & $\begin{array}{l}\text { Environmental Management Systems. } \\
\text { Environmental Load includes physical quantities of } \\
\text { matter and energy being consumed or discharged; } \\
\text { Total Cost includes quantities such as total cost of } \\
\text { waste to landfill or total cost of water consumed. } \\
\text { The overarching aim of the Framework is to increase } \\
\text { the contribution that all departments make to } \\
\text { sustainable development, improving the performance } \\
\text { of the Estate and reporting on progress. The } \\
\text { framework is being released in stages and when } \\
\text { complete will cover the main sustainable } \\
\text { development impacts associated with the running of } \\
\text { departments. The first three parts of the framework } \\
\text { include overarching commitments to identifying, } \\
\text { managing and reporting on key sustainable } \\
\text { development impacts of the Estate, as well as the first } \\
\text { suite of targets to tackle specific sustainable } \\
\text { development impacts from business travel and water } \\
\text { use. The remaining parts cover waste, energy, } \\
\text { procurement, estate management, biodiversity and } \\
\text { social impacts. }\end{array}$ & 12 \\
\hline
\end{tabular}

* The number of indicators only reflects those related to the environmental component, since in some cases the indicator frameworks also include the social and economic components.

insufficient to represent all the different environmental and sustainability scenarios.

Taking state-of-the-art environmental indicator frameworks into account, an attempt was made to use an indicator framework for environmental performance evaluation that could be applied to the public sector in general and its specific domains in particular, including individual organizations. The defence sector was chosen as a casestudy. An indicator framework was developed with the aim of combining the strengths of the most credible and tested frameworks, to eliminate potential gaps and respond to the sector-environment integration challenges.

An indicator framework to manage and assess the sector's environmental performance was developed - sectoral EPIs (SEPI) (Fig. 1). This framework was based on a rearrangement of the indicator frameworks PSR (Organization for Economic Co-operation and Development (OECD), 1993b), PSR/E (United States Environmental Protection Agency (USEPA), 1995), DPSIR (National Institute of Public Health and Environment (RIVM), 1995, and United Nations Environment Programme and National Institute of Public Health and the Environment (UNEP/RIVM) (1994)) and INDICAMP (Ramos et al., 2004c). This model seeks to incorporate a systems analysis approach, integrating the main cause-effect relationships between the different categories of performance monitoring indicators (activity, pressures, state, impacts/effects and responses). It also includes the meta-performance indicators $\left(P I_{\mathrm{m}}\right)$ category to assess the effectiveness of the performance indicators themselves. Although the sector level was the main focus of the framework, it also aims to be applicable to individual organizations or facilities.
The performance indicator framework SEPI was developed taking into account the model proposed by Carter et al. (1992) for performance indicators in public organizations, based on the main flows among input-processesoutput-outcomes. These flows are assumed as the basis for the entire EPI framework. It should be stressed that when applied to public services this approach is generally complex, as stressed by Flynn (2002) for the output measurement problems or as stated by Boland and Fowler (2000) for outcome evaluation. Despite this, the proposed framework was designed to include the main materials related to public services, along with energy, water, products, services and information flows - in particular those linked with defence missions and activities. Defence sector inputs and outputs are related with pressures on the environment but also with responses to environmental problems. Outcomes are mainly related to state and/or impacts and responses categories, and are particularly difficult to evaluate or in some cases almost impossible. In the public sector, pressure indicators (namely the components related to product/service outputs) can have unusual characteristics, as compared to business pressures. For example a product can be a policy, where the potential environmental effects (positive and negative) are mainly indirect and very difficult to assess.

This model shows how sector activities $\left(\mathrm{PI}_{\mathrm{a}}\right)$ produce pressures $\left(\mathrm{PI}_{\mathrm{p}}\right)$ on the environment, which then modify the state of the environment $\left(\mathrm{PI}_{\mathrm{s}}\right)$. The variation in state then implies impacts or effects on human health, the ecosystem and materials receptors $\left(\mathrm{PI}_{\mathrm{i}}\right)$, causing sectors/organizations and society to respond $\left(\mathrm{PI}_{\mathrm{r}}\right)$ with various management and policy measures, such as internal procedures, information, 
Table 2

Environmental indicator initiatives in the defence sector

\begin{tabular}{llll}
\hline Author/year & $\begin{array}{l}\text { Framework name: indicator } \\
\text { categories }\end{array}$ & Primary objectives/comments & $\begin{array}{l}\text { Number of } \\
\text { indicators }^{\text {a }}\end{array}$ \\
\hline
\end{tabular}

DND/CF (1997; 2000a; Measurement, analysis and 2003)
Pressure - State-Response

ISO 14031: Environmental (Operational Performance Indicators and Management Performance Indicators) Environmental Condition Indicators Environmental Performance Indicators: Leading-lagging

Department of Defense (US DoD) (1999)

Netherlands MOD (2000)

Department of National Defence and the Canadian Forces (DND/CF) (2000b)
South Africa

Department of Defence (South Africa DoD)

(2000) Performance Indicators
Environmental Performance Indicators

Strategic Performance Framework: Operational Forces-Resource Management-Defence TeamContribution to Government of Canada
The proposed performance measures were developed by the Committee on Performance Measurement for Sustainable Government Operations (PMSGO, 1999) and were adapted by the Department of National Defence and Canadian Forces as an integral component of the department's overall performance measurement process.

Using the PSR framework (OECD, 1993), they measure and report the department's progress in meeting its sustainable development commitments.

To report the military unit environmental performance based on the ISO 14031 indicator framework. They also use indicators for comparisons with other organizations and describe the extent of environmental impacts.

To evaluate the environmental performance of the United States Department of Defense (DoD), based on the process input (leading) and end-of-process or output (lagging) indicators. They refer to a variety of data on an issue being focused on (e.g. hazardous waste output); report trends in environmental conditions; and assess the effectiveness of efforts in protecting the environment. The indicator categories should address materials, energy, water and waste emissions.

Based on the Defence Environmental Policy Plan of the Netherlands Ministry of Defence, these performance indicators were developed to measure whether the 21 policy objectives have been reached or not. For each indicator the objective and certain methodological considerations are presented.

To provide managers with a common set of balanced, results-oriented performance information that will assist strategic-level decision-making and provide a basis for reporting departmental results. The Balanced Scorecard management concept was adopted as the basis for Performance Measurement. The Department has chosen to balance measurement across five key perspectives: Operational Forces; Defence Team; Leadership \& Values; Contribution to Government of Canada; and Resource Management. Each of these perspectives is subdivided into measures. Similarly, measures are divided into indicators. The Contribution to Government of Canada perspective includes the Environmental Management objective, which is measured by the following indicators: Environmental Incident Rate and Pollution Program Index. To monitor and report progress towards the objectives set out in the environmental implementation plans (EIP). The EIP for Defence is directed toward securing the capacity required by the DoD for the
$33 / 30 / 31$

Defence Sector

Military Unit

Defence Sector

Defence Sector

Defence Sector Indicators: Economic - SocialEnvironmental 
Table 2 (continued)

\begin{tabular}{llll}
\hline Author/year & $\begin{array}{l}\text { Framework name: indicator } \\
\text { categories }\end{array}$ & Primary objectives/comments & $\begin{array}{l}\text { Number of } \\
\text { indicators }^{\mathrm{a}}\end{array}$ \\
\hline
\end{tabular}

development of a national strategy for sustainable development through its line function of defence. Indicators are derived from Agenda 21.

United States

Department of Defense

(US DoD) (2001)
Pollution Prevention and Compliance Metrics: LeadingLagging
Australian Department of Defence (Australian DoD) (2002)

Marine Corps BaseCamp Lejeune (2002)

United Kingdom Ministry of Defence (UK MOD) (2003)
EPRF-Environmental Performance Reporting Framework: Government as Customer-Government as Owner-Business ProcessesPeople

Camp Lejeune Balanced Scorecard: Workforce Growth and Learning-Financial-Internal Processes-Customers

Framework for Sustainable Development on the Government Estate
To improve measurement of the DoD's impacts on the environment through leading and lagging indicators tied to the military mission. To make the metrics meaningful to senior DoD and Military Department management and understandable to nonenvironmental audiences, both inside and outside the DOD. For each indicator information is presented on the goal, the metric and who reports.

The EPRF is the means by which defence (corporately and at the site level) reports the EMS performance management requirements (monitoring, measurement and auditing, and management review). The Balanced Scorecard approach has been adapted to give a balanced indication of performance, in relation to strategic objectives. The EPRF looks at environmental performance from the same perspectives as the Defence Matters Scorecard, for the whole-of-Defence performance. Under each perspective key objectives and environmental performance indicators and measures are defined.

The Strategic Plan outlines the strategy to meet this challenge by establishing strategic goals and using the Balanced Scorecard. In each perspective area, strategic objectives and performance measures are identified and used to drive achievement of the strategic goals. The perspective Internal Processes includes enhanced environment indicators: \% implementation of Environmental Management Systems and \% Implementation of Integral Natural Resources Plan.

To assess, manage, report and improve the performance of the Government Estate. The first three parts of the framework include overarching commitments to identifying, managing and reporting on key sustainable development impacts of the Estate, as well as the first suite of targets to tackle specific sustainable development impacts from business travel and water use. The remaining parts cover waste, energy, procurement, estate management, biodiversity and social impacts. The United Kingdom Ministry of Defence (MOD) statement sets out the targets in the overarching commitments part of the framework, together with the MOD's responses to those targets. The water and travel strategy is MOD's response to the government's targets to reduce the sustainable development impacts from water management and business travel.

To guide progress and measure performance during the early stages of EMS implementation. Consistent with policy established in the Department of Defense EMS
Defence Sector

Military Unit/ Defence Sector

Military Unit

Defence Sector

Military Unit/ Defence Sector System (EMS) Implementation Criteria and Metrics 
Table 2 (continued)

\begin{tabular}{llll}
\hline Author/year & $\begin{array}{l}\text { Framework name: indicator } \\
\text { categories }\end{array}$ & Primary objectives/comments & $\begin{array}{l}\text { Number of } \\
\text { indicators }^{\mathrm{a}}\end{array}$ \\
\hline
\end{tabular}

Memo (US DoD, 2002). Fulfilment of the six criteria at each appropriate facility is the minimum necessary to meet the implementation requirement of Executive Order (EO) 13148, "Greening Government through Leadership in Environmental Management".

Marshall (n.d.) Indicators of Sustainable Development: Pressure - StateResponse

The indicators of sustainable development proposed by the United Kingdom Department of the Environment, based on the PSR framework (OECD, 1993), were adapted by the MOD for monitoring and reporting its progress towards the objectives set out in the Sustainable Development Strategy.

United States Department of Defense (US DoD) (n.d.)

United States Army (US Army) (n.d)
Environmental Performance Indicators

Army EMS Implementation Metrics
Measures of environmental performance established by the Deputy Undersecretary of Defense for Environmental Security to evaluate the services' management of their respective environmental quality and remediation programs. For each indicator the objective, the units of measurement and certain methodological aspects are presented. Adapted from DoD EMS implementation Metrics (United States Department of Defense (US DoD) (2003), it reflects the actions needed to comply with Section 401(b) of Executive Order (EO) 13148,"Greening Government through Leadership in Environmental Management" and DoD and Army EMS Policies.
Defence Sector
Army

\footnotetext{
${ }^{\text {a }}$ The number of indicators only reflects those related to the environmental component, since in some cases the indicator frameworks also include the social and economic/financial components.

${ }^{\mathrm{b}}$ Assessment Target: defence sector; military branches (Air Force, Army, Navy); units (bases, barracks, commands, among others); n.a.- - not available.
}

Missions and activities: services and/or products

(components: management/administration, operational, logistics and training/instruction)

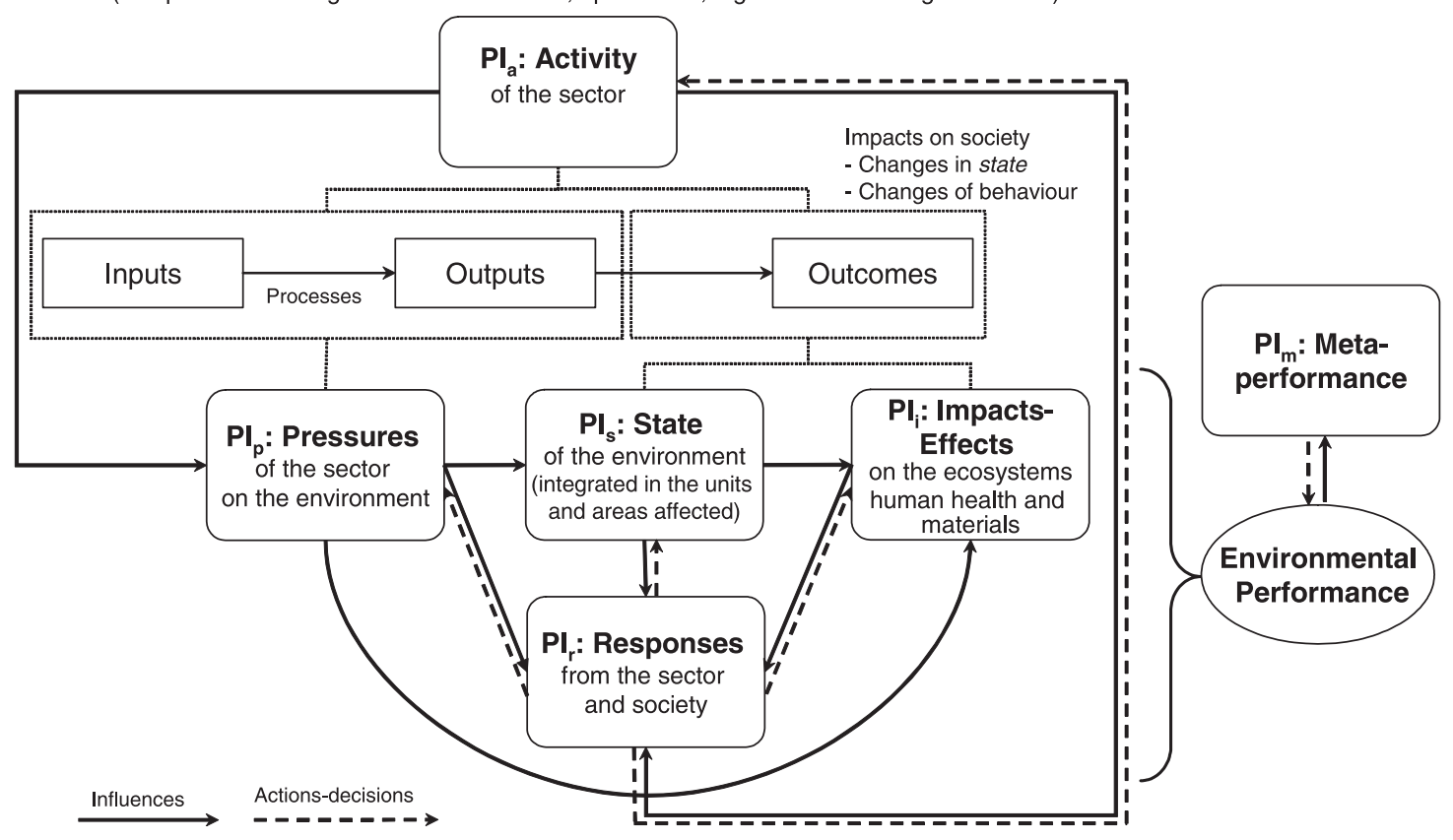

Fig. 1. Indicator framework to manage and assess the sector's environmental performance-SEPI. 
regulations and taxes (see the dashed lines in Fig. 1). The particular features of each of these categories are based on the methodologies developed by the Organization for Economic Co-operation and Development (OECD) (1993a), UNEP/RIVM (1994), RIVM (1995), United States Environmental Protection Agency (USEPA) (1995) and European Environment Agency (EEA), 2000b.

Activity indicators $\left(\mathrm{PI}_{\mathrm{a}}\right)$ are of special concern to characterize the socio-economic performance and functioning of the sector, showing the development of the sector's size and shape, as partially pointed out in EEA (2000b) for a similar indicator category. However, the complete use of $\mathrm{PI}_{\mathrm{a}}$ is beyond the scope of this work, since many of their uses are related to general sector performance management and assessment. Impacts/effects indicators $\left(\mathrm{PI}_{\mathrm{i}}\right)$ are particularly important, because they measure the actual effect on the environment of a given activity, though they are often difficult to assess. State indicators are used as data to define impact indicators.

The SEPI framework also assumes that the performance of overall environmental performance monitoring indicators can be evaluated at one main stage with the metaperformance indicators $\left(\mathrm{Pi}_{\mathrm{m}}\right)$. At this level, indicators represent the effort to conduct and implement the indicator program, also measuring their effectiveness. In a certain way, the meta-performance indicator category may be viewed as a response or management category (in ISO 14031:1999 terms), where the target is the EPI system itself. This should be distinguished from response-type indicators, which describe the responses of the sector, organizations and society and in which the targets are the environmental, social and economic systems. Meta-performance indicators show the following: (i) how appropriate the EPIs are (the activity, state, pressures, impacts/effects and responses categories), which leads to a review of and improvement in these components; (ii) an evaluation of overall monitoring activities and results, including the environmental impact of the data collecting process itself, to measure how well the indicator initiative is going; and (iii) an evaluation of the sector's environmental performance measurement system and impact mitigation action.

The indicator categories for pressures, impacts/effects (when available) and responses allow evaluation of environmental performance. Meta-performance directly evaluates the performance of all environmental indicators used and indirectly the sector's environmental performance. EEA (2000b) also stresses some of the above assumptions, stating that pressure indicators (e.g. emissions, waste flows, water use) can almost always be attributable to the implicated sectors. On the other hand, this requires modelling techniques and it is also sometimes impossible to attribute environmental state and impacts/ effects indicators to sectors. These limitations can be minimized if instead of considering the sector as a whole, we take several individual organizations as a representative sample of the sector.
Development of the EPI system is based on various fundamentals: (a) the type and dimension of the sector/ organization; (b) baseline environmental sensitivity; (c) major significant environmental aspects and/or impacts identified/predicted and related mitigation measures; (d) the identification of impacts which have poor accuracy or lack of basic data; (e) other related environmental monitoring programs; (f) the need for all public sector domains to have a common general indicator list, although sector-specific indicators exist; (g) the importance of indicators satisfying the information desires of the stakeholders (internal and external); and (i) the need for the information communicated to be potentially comparable and widely disseminated.

This indicator framework was designed to be integrated into overall performance management, since the environment is defined as an autonomous target component, which gives it a specific performance role, as happens with financial performance. The activity indicator category is the link with the performance of non-environmental issues, and can be disaggregated into another specific framework for performance evaluation of missions and activities. Integration among the various components of performance management and assessment is a fundamental issue. It should be pointed out that several pieces of research work have tried to incorporate the environment into broader performance frameworks that already have socio-economic components. Examples are certain adaptations of the balanced scorecard developed by Kaplan and Norton (1996), in particular, the work of Epstein and Young (1998), Johnson (1998) and Dias-Sardinha et al. (2002).

\section{Indicators for the Portuguese defence sector}

\subsection{The Portuguese defence sector}

The Portuguese defence sector is one of the largest in the public service, despite its relatively small size compared to those of other countries. The main characteristics of this sector are summarized in Table 3 . The data presented show the importance of this domain in the Portuguese public sector overall and in the country profile. Environmental management systems, their implementation and certification, and any environmental awards obtained by the military units were also identified.

The Ministry of Defence (Ministério da Defesa Nacional $(\mathrm{MDN})$ ) oversees a vast number of organizations (e.g. directorates general, public institutes and state-owned companies), plus the armed forces (divided into the three military branches, army, air force and navy (including marines)) and all the related organizations (e.g. bases, garrisons, agencies and commands).

Several factors justify implementing an EPI system in the Portuguese defence sector, as part of the public sector overall. These factors are, in particular: its large size (land area, personnel and installations); its spread and distribution over Portuguese territory; its complex organization; its 
Table 3

Main characteristics of the Portuguese defence sector (adapted from Ministério da Defesa Nacional (MDN), 2002)

\begin{tabular}{|c|c|c|c|c|}
\hline \multirow[t]{2}{*}{ Main sector variables } & \multirow{2}{*}{$\begin{array}{l}\text { Portuguese Defence } \\
\text { Sector }\end{array}$} & \multicolumn{3}{|l|}{ Armed Forces } \\
\hline & & Air Force & Army & $\begin{array}{l}\text { Navy (including } \\
\text { Marines) }\end{array}$ \\
\hline \multicolumn{5}{|l|}{ Personnel (number) } \\
\hline Manpower & 42677 & 7523 & 22528 & 12626 \\
\hline Total Personnel ${ }^{1}$ & 56202 & 9218 & 28422 & 17230 \\
\hline \multicolumn{5}{|l|}{ Military Units (number) } \\
\hline Total Military Units 2 & 300 & 53 & 142 & 105 \\
\hline Bases/Garrisons & 125 & 19 & 88 & 18 \\
\hline $\begin{array}{l}\text { Institutes, Academies, Schools and } \\
\text { Centres of Instruction }\end{array}$ & 76 & 25 & 26 & 25 \\
\hline \multicolumn{5}{|l|}{ Classified Buildings (number) } \\
\hline Cultural Buildings & 32 & 0 & 27 & 4 \\
\hline Buildings of Public Interest & 32 & 0 & 13 & 15 \\
\hline Occupied area (ha) & $23135^{\mathrm{a}}$ & 11559 & 10379 & 1187 \\
\hline Total expenditure $\left(10^{6} €\right)$ & $1447^{\mathrm{b}}$ & 342 & 588 & 413 \\
\hline Mission or main activities & \multicolumn{4}{|c|}{$\begin{array}{l}\text { e.g. territorial defence and military security; logistics; military instruction and training; inspection/surveillance; } \\
\text { rescuing operations; general management/administration; military exercises; marine pollution control and forest } \\
\text { fire prevention, among others. }\end{array}$} \\
\hline \multirow{6}{*}{$\begin{array}{l}\text { Military equipment available } \\
\text { (number) }\end{array}$} & \multirow[t]{6}{*}{ n.a. } & Military aircraft: & Combat cars: 101 & Warships: 50 \\
\hline & & \multirow[t]{2}{*}{124} & Armoured vehicles: 522 & Helicopters: 5 \\
\hline & & & Howitzers: 141 & $\begin{array}{l}\text { Armoured amphibious } \\
\text { vehicles: } 5\end{array}$ \\
\hline & & \multirow[t]{3}{*}{ Helicopters: 28} & Missile systems: 166 & Missile launch systems: 5 \\
\hline & & & Heavy mortars: 125 & Missiles: 13 \\
\hline & & & Bridges: 11 & Heavy mortars: 36 \\
\hline $\begin{array}{l}\text { Defence sector environmental awards } \\
\text { from } 1993 \text { to } 2002 \text { (number) }\end{array}$ & 29 & 3 & 17 & 9 \\
\hline EMS implementation (number) & 3 & 1 & 2 & 0 \\
\hline $\begin{array}{l}\text { EMS certification under ISO 14001: } \\
1996 \text { (number) }\end{array}$ & 3 & 1 & 2 & 0 \\
\hline
\end{tabular}

n.a.-not available; 1 - Civilians included; 2 - military unit was adopted to represent all the different kinds of military organizations encompassed by this study. According to this definition, one facility or camp may include several independent units that fulfil the criterion of having a person in charge of environmental issues.

${ }^{\mathrm{a}}$ About $0.25 \%$ of the Portuguese territory.

${ }^{\mathrm{b}}$ About $1.2 \%$ of GDP and $3.2 \%$ of public sector expenditure.

important number of missions, activities, products and services; its potential environmentally significant impacts; its large acquisition processes; its significant public expenditure; its profile and awareness of fair environmental management practices; its growing role in modern society and, finally, its general exclusion from environmental studies under European and Portuguese law such as the environmental impact assessment regulations.

The increasing environmental integration in the Portuguese military units may indeed become an example for the rest of the public sector to develop better practices. Some practices and indicators in the defence sector are similar to those in the private sector. Others are specific to the public service and may well be replicated in other public institutions that are taking more time to adopt environmental management practices. Still others are specific to the military, often being those with the most significant impacts; they may have less demonstration value, but they are of course important for local impact reduction.
Unlike the classic business input-output model, the main mission of a country's national defence system is to defend and protect its sovereignty and interests, i.e. the major "product" output flow. The inputs and outputs in defence can generally be represented by Fig. 2. On the basis of environmental field assessments, national questionnaire surveys (Ramos et al., 2004a) and the literature, the typical defence flows were identified (see Fig. 2). This scheme represents the main inputs from the environmental and socio-economic systems necessary to assure that the defence sector works, at the process, facility and equipment levels. Consequently, outputs originate from defence activities and are released into the interacting natural and human systems. Many of these inputs and outputs represent the main groups of the defence services' potential environmental pressures that may influence the environment and modify the state of the ecological and social systems. Despite certain general assumptions, this flowchart could represent the main inputs, processes and 


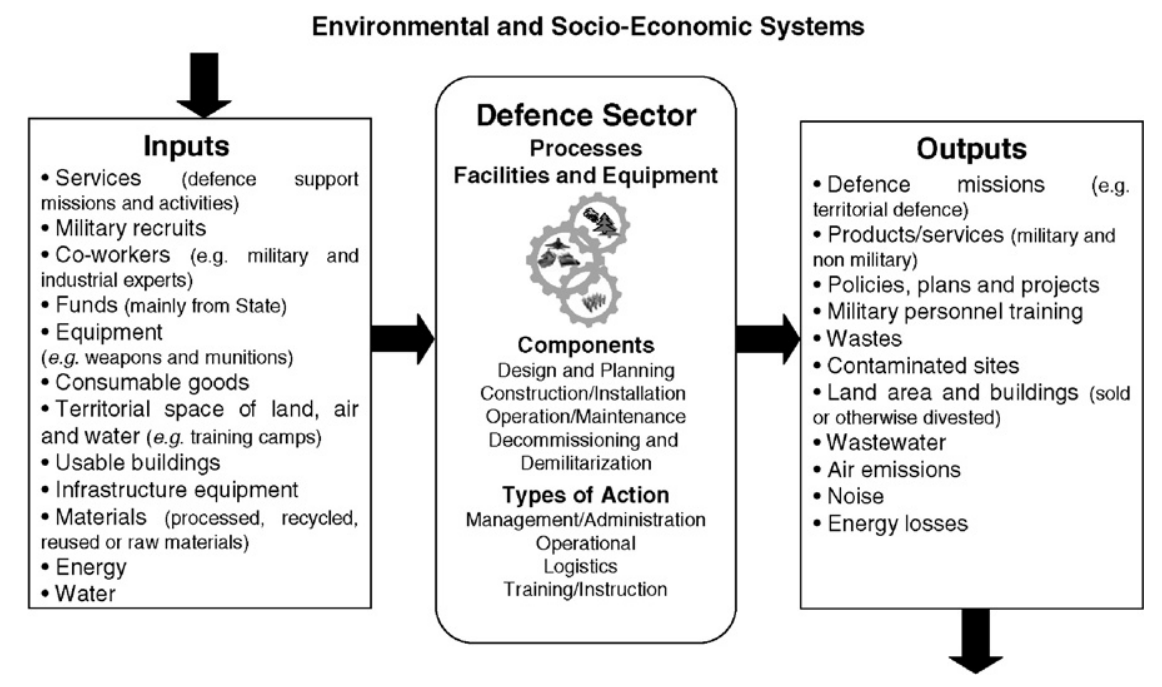

Fig. 2. Simplified chart flow of inputs and outputs in the defence sector.

outputs in the Portuguese defence sector, and be of special value for indicator development.

\subsection{Development of Indicators}

In this study the main object of analysis is the whole defence sector. It is, however, divided into several components, including the armed forces and the administrative agencies/departments, covering military and civilian components. As the business sector can be divided into the corporate, company, site or facility levels, the defence sector can also be disaggregated into several organizational levels. Accordingly, the application of the SEPI framework to the Portuguese defence services was carried out with two organizational levels in mind: $\mathrm{L}_{1}$ - the overall defence sector (the military branches - the Air Force, Army and Navy - and all organizations under the Ministry of Defence); and $\mathrm{L}_{2}$ - military units (e.g. bases, garrisons, agencies and commands). In association with these levels the information could be reported at two spatial levels: national or local. In this paper, where the main aims are sector-oriented, only the national level will be considered.

The indicators were developed particularly to satisfy policy level needs, i.e. the set proposed is made up of key environmental defence-sector indicators. These indicators should be able to communicate the sector's environmental performance to policy makers, military chiefs and the general public. These indicators have a high information content and reduced complexity and are relevant for the target audience. Although the aggregation of indicators into indices is more attractive to top decision-makers and the general public, headline indicators could simply be single quantitative or qualitative indicators with a special meaning, fulfilling the objectives desired.

Despite some degree of specificity, the indicators developed for the Portuguese defence sector are naturally common to other defence sectors throughout the world, and to the other public and private domains. Even so, to satisfy the sector-specific characteristics, a methodological procedure was carried out to accomplish the final goal, the development of EPPIs (Fig. 3).

In the first stage, the sector profile assessment was conducted using the following fundamental steps developed in previous work (Ramos and Melo, 2005, 2006; Ramos et al., 2004a, b):

(a) A review of sector mission and activity characteristics: inputs, processes, outputs and, when possible, the outcomes; a clear description of their estate, including type and/or number of organizations, staff, buildings and facilities, land area owned, and material and equipment managed.

(b) Systematic analysis of the integration of environmental considerations into defence sector policies, centered on the following elements: the environmental policy of the Portuguese Armed Forces (Ministério da Defesa Nacional (MDN), 2001); the NATO Standardization Agreement (STANAG $7141 \mathrm{EP}-1$ st edition) (North Atlantic Treaty Organisation (NATO), 2002).

(c) The sector's environmental profile: based on an assessment of the environmental management practices implemented.

(d) Identification of the environmental aspects and impacts (significant and non significant).

(e) The state of environmental performance evaluation in the Portuguese defence services.

It was principally the information obtained at this stage that was used as the basis for the development of the sectoral environmental performance policy indicator.

Therefore, after these phases (a-e) had been carried out, the indicators were developed (phases $\mathrm{f}-\mathrm{i}$ ). On the basis of the pre-defined goals and objectives for the indicator system to be developed, various indicator guidelines and criteria were taken into account, namely those presented by Johnston and Smith (2001), Wehrmeyer et al. (2001), 


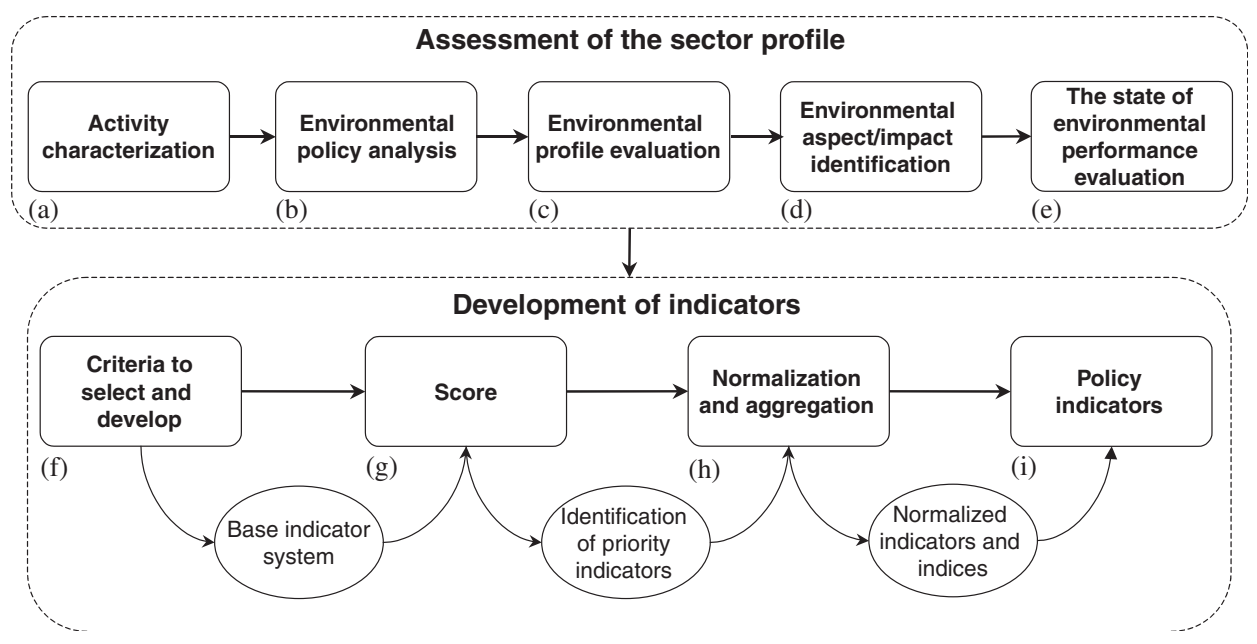

Fig. 3. Phases (a-i) used in the development of the environmental performance policy indicators.

International Organisation for Standardization (ISO) (1999), Young (1996), Kuhre (1998), Personne (1998), Her Majesty's Stationery Office (HMSO) (1996), Ramos (1996), Barber (1994), UNEP/RIVM (1994) and Ott (1978).

Some of the most relevant criteria used in this phase were: social and environmental relevance; ability to provide a representative picture of significant environmental aspects and impacts; the extent to which it fits into the conceptual framework; to be goal driven; simplicity, ease of interpretation and ability to show trends over time; responsiveness to change in the environment and related project actions; capacity to give early warning about irreversible trends; ability to be updated at regular intervals; present or future availability at a reasonable cost/benefit ratio; appropriateness of scales (temporal and spatial); acceptable levels of uncertainty; data collection methods comparable with other data sets; a good theoretical base in technical and scientific terms; existence of a target level or threshold against which to compare it so that users are able to assess the significance of the values associated with it; and minimal environmental impact of the sampling process itself.

When a base indicator system had been obtained (see Appendix A), a scoring procedure was used, following the method developed by Ramos et al. (2004c). To obtain the headline indicator core set, avoiding a too complex and resource-demanding system, the SEPI indicators could be scored according to a qualitative expert knowledge assessment of their relevancy and feasibility, which included some of the above mentioned criteria, though in a more focused evaluation. The relevancy classification covers: (i) the association with major and actual sectoral environmental integration policy issues; (ii) links with policy targets or scientifically/technically determined reference values; (iii) the technical and scientific importance; (iv) the synthesis capability; (v) the usefulness in communicating with and reporting to a wide audience; and (vi) the appropriateness to the organization level. The feasibility classification covers: (i) sensibility; (ii) robustness; (iii) cost; and (iv) the operability of the determination methods. Some of the properties used to assess relevancy and feasibility coincide with the criteria for headline and sector policy indicator selection that are mentioned by the Commission of the European Communities (2003), Organization for Economic Co-operation and Development (OECD) (2001), Hertin et al. (2001), the EEA (2000b), Swedish Environmental Advisory Council (SOU) (1999), the Commission of the European Communities (1999) and the European Environment Agency (EEA) (n.d.).

To proceed with the qualitative assessment for evaluating relevancy and feasibility classes, an expert panel was set-up, composed of academics and MDN staff with environmental and defence expertise. In the first stage only the indicators with the highest classification were included, keeping in mind that, when adding up this score, the total number of indicators should not exceed, on average, 7 indicators per category. Each indicator was classified from 1 (lowest classification) to 3 (highest classification): low-1; medium - 2; high - 3. The headline indicators used in SEPI were those with a score of 6 (the sum of relevancy and feasibility). Relevancy was the main criteria for indicator selection, followed by the feasibility of the indicator determination method. The other indicators scored were to be considered for other kinds of performance evaluation (Table 4). A final post-scoring was conducted to assure that the core set of indicators obtained represented the real situation in the Portuguese defence sector: a check was made that the significant environmental aspects and impacts identified for the sector in Ramos et al. (2004a) were reflected in the indicators chosen.

The EPPIs obtained and their results should be reviewed periodically to identify opportunities to improve and reach the objectives. A special attribute of this framework is the possibility of obtaining a significant part of the review information from the meta-performance indicators. Some of the steps in the reviewing process can include a review of certain points similar to those presented by International Organisation for Standardization (ISO) (1999), namely: the 
Table 4

Score for indicators according to their relevancy and feasibility (classification: 1-low; 2-medium; 3-high)

\begin{tabular}{lll}
\hline Score & Relevancy & Feasibility \\
\hline 1st & 3 & 3 \\
2nd & 3 & 2 \\
3rd & 3 & 1 \\
4 th & 2 & 3 \\
5 th & 2 & 2 \\
6 th & 2 & 1 \\
7 th & 1 & 3 \\
8 th & 1 & 2 \\
9 th & 1 & 1 \\
\hline
\end{tabular}

appropriateness of the monitoring scope and objectives; the cost effectiveness and benefits achieved; the progress towards meeting environmental performance criteria; the appropriateness of environmental performance criteria; the appropriateness of SEPI indicators; and data sources, data collection methods and data quality.

The indicators can be produced in three formats: absolute; normalized or aggregated into an index. In general, to evaluate environmental performance these various possibilities are complementary and should be used as a function of the objectives. Absolute indicators state the magnitude of the environmental problem, the normalized indicators allow us to associate with the efficiency, and the indices communicate aggregate information by adimensional units, for example by pollution, quality or performance classes. Targeting the top decision makers or the general public, as policy indicators do, the information should be in the easiest and most succinct format. Therefore, a key procedure is the transformation of the collected data into adequate units of measurement and the normalization of indicators, in order to allow comparability and make the data available to different target audiences. For this indicator system we propose a range of normalizing factors (common denominators) to produce the results:

- functional unit ${ }^{1}$ - major defence missions (e.g. territorial defence; military exercises), defence products (e.g. cartography; military equipment) and services (e.g. marine environmental surveillance for the Ministry of the Environment) (number).

- Members of staff (military plus civilian personnel) (number).

- Building area (ha).

- Military units (number).

- Public environmental investments and expenses $(€)$.

\footnotetext{
${ }^{1}$ Standard unit of production appropriate to the sector, as defined by Berkhout et al. (2001).
}

Nevertheless, the choice between normalized or absolute indicators will depend mainly on the objective. As stressed by Characklis and Richards (1999) there is no analytical solution to this basic divergence of goals, i.e. someone interested in eco-efficiency might see the productionweighted indicator as consistent with the overriding goal of less environmental impact per unit product. A local community would likely find the total environmental loading to be more important.

Overall indicators should be evaluated for the entire Portuguese defence sector and also disaggregated by service branch, the Air Force, Army and Navy, when appropriate.

The SEPI framework provides for the possibility that indicators can be aggregated by category into environmental indices (by arithmetic or heuristic algorithms), reflecting the composite results of each framework category. As a result, the environmental performance could ideally be presented with an index for each indicator category: activity, pressure, state, impact-effects, response and meta-performance. Some of the methodological drawbacks of environmental indices and weighting must be taken into account, to avoid significant losses of information and assure meaningful results.

A system of about 135 indicators for SEPI framework categories was developed as a base to obtain, by scoring, the core set of headline indicators for the Portuguese defence sector. Some of the indicators belonging to this system were also chosen on the basis of previously mentioned literature, presented in Tables 1 and 2, and of the criteria for indicator selection and development presented earlier.

Table 5 presents the core set of indicators obtained after scoring the long list of 135 indicators from 1 to 3, for their relevancy and feasibility. Indicators are divided by SEPI category, and examples of units of measurement are given for each indicator. It became clear that this headline core set, despite their sector specificity, should cover all major environmental issues/problems, and many of those indicators are also applicable on the macro level (national sector level) and micro-level (i.e. public agency, firm or corporate level). Nevertheless, it should be stressed that some of the indicators have no meaning when analysed at micro-level.

Despite the efforts to obtain an equilibrated core set of headline indicators, quantitatively and qualitatively, the total number of indicators is still high. This is a problem, although mitigated by the fact that different categories of indicators are directed at specific goals. Hence, most indicators will simply not be needed in any one particular situation. As stated in EEA (n.d.), in recent years there has been a trend to develop a more limited number of indicator core sets, in particular when dealing with headline indicators. However, there is not a widely accepted consensus on the length of the list of "typical" headline indicators, except that there should only be a few (e.g. from 5 to 30$)$. 
Table 5

Environmental performance policy indicators, according to SEPI categories, for the Portuguese defence sector

\section{Activity}

$\mathrm{PI}_{\mathrm{a} 1}$-Personnel (military and civilian)

$\mathrm{PI}_{\mathrm{a} 2}-$ Public expenditure

$\mathrm{PI}_{\mathrm{a} 3}$-Defence missions and activities: production and storage of military weapons, ammunition and other military-type goods; operation, maintenance and repair of military/non-military buildings, machinery and equipment (including vehicles); military field exercises; inspection/ surveillance; rescuing operations; demilitarization; defence research and development initiatives; total missions and activities

$\mathrm{PI}_{\mathrm{a} 4}$ - Travelling on duty: air, road, boat and railway (by vehicle fleet)

$\mathrm{PI}_{\mathrm{a}}$ - Defence organizations: military units and others

$\mathrm{PI}_{\mathrm{a} 6}$ _Land area owned, leased or managed (by land use type and by military activity, in particular training and exercises)

$\mathrm{PI}_{\mathrm{p} 7}$ Conventional ammunition, missiles and explosives used or detonated (by type)

Pressures

$\mathrm{PI}_{\mathrm{p} 1}$-Energy consumption: total and by source (renewable and nonrenewable)

$\mathrm{PI}_{\mathrm{p} 2}$ - Fuel consumption (by equipment/vehicle fleet): total and by fuel type (natural gas, light oil, heavy oil, diesel, propane, steam)

$\mathrm{PI}_{\mathrm{p} 3}$ - Spills of oil, fuel or hazardous substances

$\mathrm{PI}_{\mathrm{p} 4}$-Wastewater discharges: domestic sources, industry and contaminated stormwater:

metals and compounds, chlorinated organic substances, other organic compounds (e.g. total organic carbon-TOC; Polycyclic aromatic hydrocarbons - PAH), suspended solids, nutrients (total nitrogen and phosphorus), sediment from runoff (see European Pollutant Emission Register-EPER)

$\mathrm{PI}_{\mathrm{p} 5}$-Air emissions from stationary and mobile sources $\left(\mathrm{SO}_{2} ; \mathrm{NO}_{\mathrm{x}}\right.$;

$\mathrm{PM}_{10}$; VOCs; CO; heavy metals) (see EPER)

$\mathrm{PI}_{\mathrm{p} 6}$ - Solid waste generation by type: hazardous and non-hazardous wastes; military equipment and ammunition wastes; domestic, industrial, medical, forestry, garden, agricultural, construction and demolition wastes; sludge from wastewater treatment plants

State

$\mathrm{PI}_{\mathrm{s} 1}$ - Soil contamination (e.g. metal contamination such as iron, aluminium, copper, tungsten, depleted uranium and lead)

$\mathrm{PI}_{\mathrm{s} 2}$ Soil eroded and compacted

$\mathrm{PI}_{\mathrm{s} 3}$ Air quality $\left(\mathrm{SO}_{2} ; \mathrm{NO}_{\mathrm{x}} ; \mathrm{PM}_{10}\right.$; VOCs; $\mathrm{CO}$; heavy metals) (within unit areas and outside)

$\mathrm{PI}_{\mathrm{s} 4}$ - Surface and groundwater quality by water uses (microbiologic and physical-chemical indicators): agriculture; industrial processes; washing; domestic supply; ecological protection; recreation purposes, among others

$\mathrm{PI}_{\mathrm{s} 5}$ - Noise levels (with and without defence activities, particularly exercises): (within the unit area and outside)

$\mathrm{PI}_{\mathrm{s} 6}$ - Endangered species of flora and fauna

Impacts-effects

$\mathrm{PI}_{\mathrm{i} 1}$ - Health effects (staff and local communities)

$\mathrm{PI}_{\mathrm{i} 2}$-Noise impacts on population

$\mathrm{PI}_{\mathrm{i} 3}$ - Cultural heritage degradation, including historic properties, archaeological sites, and more traditional cultural sites

$\mathrm{PI}_{\mathrm{i} 4}$ - Biotic communities disturbance

$\mathrm{PI}_{\mathrm{i} 5}$-Effects on the quality of organisms used in human diet (e.g. marine organisms)

$$
\begin{aligned}
& \text { No } \\
& 10^{6} € \text { year }^{-1}
\end{aligned}
$$$$
\text { No year }{ }^{-1}
$$

km year $^{-1}$

no.

$\mathrm{Ha}$

no year ${ }^{-1}$

$$
\begin{aligned}
& \text { Jyear }^{-1} \\
& \text { tyear }^{-1} ; \mathrm{m}^{3} \text { year }^{-1} \\
& \text { no.year } \\
& \mathrm{m}^{3} \cdot \text { year }^{-1} ; \mathrm{m}^{3} \cdot \text { year }^{-1} ; \text { t.year }^{-1} \\
& \text { tyear }^{-1} \text { by pollunt equivalent; }
\end{aligned}
$$

t.year ${ }^{-1}$ by pollutant

tyear $^{-1}$

no. of contaminated sites; ha; $\mathrm{m}^{3}$

$\mathrm{Ha} ; \%$

$\mu \mathrm{g} \mathrm{m}^{-3}$; no. of days exceeding air quality standards year ${ }^{-1}$

$\mathrm{mgl}^{-1} ; \%$ of non-compliance samples year ${ }^{-1}$; MPN.100 $\mathrm{ml}^{-1}$ (for microbiological parameters)

No. of sites exceeding noise levels limits year ${ }^{-1}$

No. of species

blood lead levels: ppm

$\%$ of population highly annoyed

Qualitative assessment

Community disturbance assessments; number animals deaths year ${ }^{-1}$

Presence of faecal contamination in bivalvia (MPN indicator of faecal contamination $\mathrm{FW}^{-1}$ )

$\%$ population served by wastewater treatment plants 
Table 5 (continued)

Indicators categories

$\mathrm{PI}_{\mathrm{r} 2}$-Disposal, treatment and recycling of wastes, in particular hazardous wastes, military equipment and ammunition wastes (disposal to landfill, incineration, recycling, composting and energy from waste) $\mathrm{PI}_{\mathrm{r} 3}$ - Personnel with environmental tasks (individual equivalent to $100 \%$ daily task time)

$\mathrm{PI}_{\mathrm{r} 4}$ - Environmental training (at all organization levels)

$\mathrm{PI}_{\mathrm{r} 5}$ - Environmental Management Systems (EMS) in place (EMAS (European Parliament and the Council of the European Union, 2001) and/or ISO 14001: 1996 or ISO 14001: International Organisation for Standardization (ISO) (2004) registered EMS)

$\mathrm{PI}_{\mathrm{r} 6}$-Environmental considerations in systems acquisition processes (e.g. new weapons systems)

$\mathrm{PI}_{\mathrm{r} 7}$-Environmental reporting and communication on defence sector's environmental activity

$\mathrm{PI}_{\mathrm{r} 8}$-Effective internal and external stakeholder relationships

$\mathrm{PI}_{\mathrm{r} 9}$ - Environmental budgeting, costs (reactive and proactive) and investments

$\mathrm{PI}_{\mathrm{r} 10}$-Environmental missions/services (e.g. forest fire prevention; marine pollution prevention and combat)

Meta-performance

$\mathrm{PI}_{\mathrm{m} 1}$ - Identification of unexpected environmental aspects and impacts

$\mathrm{PI}_{\mathrm{m} 2}-$ Effectiveness of mitigation and management measures

$\mathrm{PI}_{\mathrm{m} 3}$-Environmental performance evaluation investments and expenses

$\mathrm{PI}_{\mathrm{m} 4}$ - Institutional cooperation with other monitoring activities (e.g. monitoring programs managed by Ministry of the Environment)

$\mathrm{PI}_{\mathrm{m} 5}$ - Implementation of new environmental practices on the basis of performance results

$\mathrm{PI}_{\mathrm{m} 6}$ - Environmental staff with performance measuring as a daily task (individual equivalent to $100 \%$ daily task time)

$\mathrm{PI}_{\mathrm{m} 7}$-Revisions of indicators

Units (examples) ${ }^{\mathrm{a}}$

$\%$; tyear $^{-1}$

No year ${ }^{-1}$

$\%$ of total number of staff; average hours of environmental instruction and training person ${ }^{-1}$ year $^{-1}$; no. of environmental education and awareness-raising initiatives

$\%$; no.

$\%$; no. of contracts with environmental conditions

No. of disclosures year ${ }^{-1}$; no of environmental reports year ${ }^{-1}$; no of environmental workshops year ${ }^{-1}$; no. of environmental and defence internet sites

No. of positive and negative enquiries from stakeholders year ${ }^{-1}$; no. of meetings with stakeholders' representatives year ${ }^{-1}$

$10^{3} €$ year $^{-1}$

no. of man-days year ${ }^{-1}$; no. of missions year ${ }^{-1} ; €$

$\% ;$ no year
$\%$; no. of mitigation measures redesigned
$10^{3} €_{\text {year }}{ }^{-1}$
No.
No year
No.
No of revisions year

${ }^{a}$ For each indicator unit of measurement presented, the appropriate normalizing factors (functional unit; members of staff (number); building area (ha); military units (number); public environmental investments and expenses (euros)) should be chosen.

The use of different categories allows the incorporation of a system analysis approach and the identification of the main cause-effect relationships between indicators. Indicator categories are also meant to minimize the usual practice of only developing pressure indicators or, even worse, management indicators. In large operations such as military facilities, the use of local environment-related indicators (state and impact-effects) is important.

Headline indicators should aim at transmitting a message to a wide audience. The set selected for the Portuguese defence services includes, in some cases, indicators that need some technical background to understand the message. This limitation can be minimized through the use of normalization and aggregation procedures. Even so, this does not mean that headline indicators should always be highly aggregated. As mentioned in EEA (n.d.), it depends on the policy question whether aggregation or selection is the best strategy to arrive at a headline indicator.
Furthermore, the work carried out in the public sector and, on a separate basis, the defence sector (see examples presented in Tables 1 and 2) shows that some of the indicator systems have similar limitations with the relatively high number of indicators and the technical specificity of some measures; examples are the work carried out by The Committee on Performance Measurement for Sustainable Government Operations (PMSGO) (1999) for the public sector and Netherlands Netherlands Ministry of Defence (Netherlands MOD), 2000 and Department of National Defence and the Canadian Forces (DND/CF) (1997, 2000a, 2003) for the defence sector.

The major difficulty in accomplishing environmental performance evaluation objectives is to assess whether the environmental changes observed are caused by that specific sector's activity or whether other factors have intervened. As discussed by Ramos et al. (2004c) for monitoring project indicators, causality can be a problematic issue when, on the basis of the performance measurement results, 
a decision-maker decides that mitigation measures have to be taken. Besides, the environmental problems may not originate from a single activity but from the cumulative processes and synergetic effects of the combined polluting activities in an area. However, an integrated area-oriented approach can help to identify the cumulative and synergetic character of environmental problems, since the total impact of the various activities in an area is monitored. That is why it is important to be aware of other monitoring programs in the study area (Arts et al., 2000).

As with several other indicator frameworks such as PSR or DPSIR, SEPI tends to suggest linear relationships in sector activities and environmental impacts-effects. However, this should not obstruct the view of more complex relationships between activities, pressures, the state of environmental changes, environmental impact-effect interactions and responses. The proposed framework does not attempt to make one-to-one linkages between each specific indicator category, since the environmental performance depends on the total, multiple and complex relationships between indicators. In opposition to other indicator frameworks, prevention is assumed as a priority in SEPI. Response indicators should be in place not only when environmental effects occur (after changes in the state of the environment or impact-effects on ecosystems and public health are identified), but also be directly linked to the first categories of the framework, i.e. the activity and pressure indicators.

One important practical step in this work will be to apply the framework and associated headline indicator system developed to real data. This process will allow the usefulness the of approach to be evaluated. To assure a feasible application in the near future the activity, pressure and response indicators should have priority in the implementation, as data for these categories are most easily obtained. Throughout this phase comparisons with the results of other countries' armed forces (e.g. the environmental report for the defence services of the United Kingdom, United Kingdom Ministry of Defence (UK MOD) (2002)) should be made to help the evaluation process.

As mentioned before, the SEPI conceptual model may be exploited to develop indicators for other public services. Of course, for each public domain there will be specific indicators, besides common components that are valid for the private and public domains overall.

\section{Conclusions}

At present there is significant diversity in the indicator frameworks available for evaluating environmental and sustainability performance. This diversity is at the root of the increased difficulty in providing comparisons among organizations, sectors and countries. EPIs in the public sector are a recent issue, in particular in the defence services, with little literature available. Most of the work conducted for the defence sector does not use formal indicator frameworks or other types of methodological support.
Based on a reasoned rearrangement of the environmental indicator frameworks PSR, PSR/E, DPSIR, ISO 14031 and INDICAMP, a conceptual methodology to manage and assess the sector's environmental performance-SEPI-has been presented and discussed. This model allows the incorporation of a systems analysis approach and the identification of the main cause-effect relationships between the different categories of environmental performance policy indicators. To assure the effectiveness of performance indicators, an assessment tool was included in the SEPI framework - the meta-performance indicator category.

The indicators developed were the first step in an evaluation of the Portuguese defence sector's environmental performance. This stage also illustrated the drawbacks, limitations and usefulness of the SEPI framework. Certain difficulties arose in choosing the indicators for each category and in finding system interactions. Despite the effort to limit the number of indicators per framework category, in future tests and applications the total number of indicators used should be optimized, since the objective should be to achieve a further reduction. To improve the usefulness of the indicator system certain areas should be given priority, namely it should be even more workable and comparable with other indicator frameworks. Taking into account these concerns for future developments, the framework seeks to contribute to evaluating the sector's environmental performance and find simple relationships between defence missions and operations and environmental impacts-effects.

To evaluate the effectiveness of the proposed EPPIs real data should be gathered and used for reporting the sector's environmental performance results. Only with effective practice can improvements be made in the indicator framework and indicators chosen for each category.

Although developed for the defence sector, the conceptual framework developed could be applied to other public sectors, thus making the reporting of environmental performance data more comparable among public organizations and making it easier for the decision makers and general public to handle. Of course, extrapolation to other public services should be done with due care.

\section{Acknowledgments}

We would like to express our thanks for the support of the Portuguese Ministry of Defence (MDN). The first author had a PRAXIS XXI/BD/15973/98 scholarship, financed by the ESF (European Social Fund). We would like also to acknowledge the invaluable collaboration of Ms. Isabel Leitão and Mr. Álvaro Estrela Soares from the MDN.

\section{Appendix A}

Environmental performance indicators (base indicator system), belonging to SEPI categories, for the Portuguese defence sector are shown in Table A1. 
Table A1

Environmental performance indicators (base indicator system), belonging to SEPI categories, for the Portuguese defence sector

\begin{tabular}{|c|c|c|c|}
\hline Indicators categories & Units (examples) ${ }^{\mathrm{a}}$ & Score relevancy & Feasibility \\
\hline \multicolumn{4}{|l|}{ Activity } \\
\hline $\mathrm{PI}_{\mathrm{a} 1}$-Personnel (military and civilian) & No & 3 & 3 \\
\hline $\mathrm{PI}_{\mathrm{a} 2}$-Public expenditure & $10^{6} €$ year $^{-1}$ & 3 & 3 \\
\hline $\mathrm{PI}_{\mathrm{a} 3}-$ Total procurement budget & $€$ year $^{-1}$ & 2 & 3 \\
\hline $\mathrm{PI}_{\mathrm{a} 4}$-Defence missions and activities: production and & No year ${ }^{-1}$ & 3 & 3 \\
\hline
\end{tabular}

storage of military weapons, ammunition and other militarytype goods; operation, maintenance and repair of military/ non-military buildings, machinery and equipment (including vehicles); military field exercises; inspection/surveillance; rescuing operations; demilitarization; defence research and development initiatives; total missions and activities

$\mathrm{PI}_{\mathrm{a} 5}$-Travelling on duty: air, road, boat and railway (by vehicle fleet)

$\mathrm{PI}_{\mathrm{a} 6}$ - Transports of goods (by train, truck, ship): goods/ materials, machinery and equipment; total

$\mathrm{PI}_{\mathrm{a}}$ _ Defence organizations: military units and others

$\mathrm{PI}_{\mathrm{a} 8}$ _Vehicle parking area

$\mathrm{PI}_{\mathrm{a}}$ _ Land area owned, leased or managed (by land use type and by military activity, in particular training and exercises) $\mathrm{PI}_{\mathrm{p} 10}$ - Conventional ammunition, missiles and explosives used or detonated (by type)

Pressures

$\mathrm{PI}_{\mathrm{p} 1}$-Energy consumption: total and by source (renewable and non-renewable)

$\mathrm{PI}_{\mathrm{p} 2}$ - Fuel storage tanks

$\mathrm{PI}_{\mathrm{p} 3}$-Fuel consumption (by equip./vehicle fleet): total and

by fuel type (natural gas, light oil, heavy oil, diesel, propane, steam)

$\mathrm{PI}_{\mathrm{p} 4}$-Electricity consumption

$\mathrm{PI}_{\mathrm{p} 5}$ - Gas consumption

$\mathrm{PI}_{\mathrm{p} 6}$-Water consumption: (i) total, surface and

groundwater; (ii) total and by water use: e.g. agriculture;

industrial processes; washing; domestic supply

$\mathrm{PI}_{\mathrm{p} 7}$-Spills of oil, fuel or hazardous substances

$\mathrm{PI}_{\mathrm{p} 8}$ - Wastewater discharges: domestic sources, industry and contaminated stormwater:

metals and compounds, chlorinated organic substances, other organic compounds (e.g. total organic carbon-TOC;

Polycyclic aromatic hydrocarbons-PAH), suspended solids, nutrients (total nitrogen and phosphorus), sediment from runoff (see European Pollutant Emission Register-EPER) $\mathrm{PI}_{\mathrm{p} 9}$-Air emissions from stationary and mobile sources ( $\mathrm{SO}_{2} ; \mathrm{NO}_{\mathrm{x}} ; \mathrm{PM}_{10}$; VOCs; $\mathrm{CO}$; heavy metals) (see EPER) $\mathrm{PI}_{\mathrm{p} 10}$-Solid waste generation by type: hazardous and nonhazardous wastes; military equipment and ammunition wastes; domestic, industrial, medical, forestry, garden, agricultural, construction and demolition wastes; sludge from wastewater treatment plants

$\mathrm{PI}_{\mathrm{p} 11}$ - Hazardous waste storage

$\mathrm{PI}_{\mathrm{p} 12}$ - Generation of noise and vibrations (by frequency intervals)

$\mathrm{PI}_{\mathrm{p} 13}$ - Facilities left abandoned

$\mathrm{PI}_{\mathrm{p} 14}$ - Building, machinery and equipment heat losses

$\mathrm{PI}_{\mathrm{p} 15}$-Material use: raw materials, processed, recycled and reused (including consumable goods)

$\mathrm{PI}_{\mathrm{p} 16}$-Consumption of hazardous/toxic materials

$\mathrm{PI}_{\mathrm{p} 17}$-Use of ozone depleting substances (products and equipments)

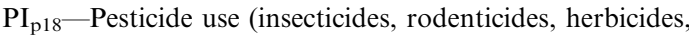
disinfectants and repellents)

$\mathrm{PI}_{\mathrm{p} 19}$-Fertilizer use

$\mathrm{PI}_{\mathrm{p} 20}$ - Greenhouse gases (chemical consumption/gas

emissions): direct emissions from sources owned or controlled

$\mathrm{km} \mathrm{year}^{-1}$
$\mathrm{~km}^{-1}$ year $^{-1}$
No.
Ha
Ha
No year
$\mathrm{J} \mathrm{year}^{-1}$
$\%$ of tanks in non-compliance $_{\mathrm{t} \text { year }}^{-1} ; \mathrm{m}^{3}$ year

$\mathrm{kWh}^{-1}$ year
$\mathrm{M}^{3}$ year $^{-1}$
$\mathrm{M}^{3}$ year $^{-1}$

3

3

1

3

3

2

No year ${ }^{-1} ; \mathrm{m}^{3}$ year $^{-1} ;$ t year $^{-1}$

$\mathrm{m}^{3}$ year $^{-1}$; inhabitant equivalent;

t year $^{-1}$ by pollutant

t year $^{-1}$ by pollutant

t year -1

3

$\mathrm{t} \mathrm{m}^{3}$

W

No year ${ }^{-1} ; 0$

$\mathrm{J} \mathrm{m}^{-3} ; \mathrm{J} \mathrm{m}^{-2}$

tyear $^{-1} ; \mathrm{m}^{3}$ year $^{-1}$

tyear $^{-1} ; \mathrm{m}^{3}$ year $^{-1}$

t year $^{-1}$;

t year ${ }^{-1}$

t year $^{-1}$

$\mathrm{t} \mathrm{CO}_{2}$ equivalents year ${ }^{-1}$
3

2

2

3

2

3

2

3

3

3

3

3

3

3

3

2

2

1

2

1

1

3

3 
Table A1 (continued)

Indicators categories
by the defence sector; indirect emissions from imported
electricity, heat or steam (from infrastructure, commercia

electricity, heat or steam (from infrastructure, commercial

vehicles, military vehicles and equipment)

$\mathrm{PI}_{\mathrm{p} 21}$-Amount of impermeable surface

$\mathrm{PI}_{\mathrm{p} 22}$ - Non-compliance events

$\mathrm{PI}_{\mathrm{s} 23}$-Emergency episodes (e.g. fires, explosions)

$\mathrm{PI}_{\mathrm{s} 24}$-Vehicles circulating (in particular in sensitive natural areas)

$\mathrm{PI}_{\mathrm{p} 25}$-Forest fires

Units (examples) ${ }^{\mathrm{a}}$

Score relevancy

Feasibility

State

$\mathrm{PI}_{\mathrm{s} 1}$ - Soil contamination (e.g. metal contamination such as iron, aluminium, copper, tungsten, depleted uranium and lead)

$\mathrm{PI}_{\mathrm{s} 2}$ - Land use (forestry, agriculture, residential, administrative, military infra-structure and equipment) $\mathrm{PI}_{\mathrm{s} 3}$ - Soil eroded and compacted

$\mathrm{PI}_{\mathrm{s} 4}$ - Land abandonment

$\mathrm{PI}_{\mathrm{s} 5}$-Vegetation cover by type

$\mathrm{PI}_{\mathrm{s} 6}-$ Air quality $\left(\mathrm{SO}_{2} ; \mathrm{NO}_{\mathrm{x}} ; \mathrm{PM}_{10} ; \mathrm{VOCs} ; \mathrm{CO}\right.$; lead, black smoke) (within unit areas and outside)

$\mathrm{PI}_{\mathrm{s} 7}-$ Indoor air quality

$\mathrm{PI}_{\mathrm{p} 8}$-Radiation levels

$\mathrm{PI}_{\mathrm{s} 9}$ - Surface and groundwater quality by water uses (microbiological and physical-chemical indicators): agriculture; industrial processes; washing; domestic supply; ecological protection; recreation purposes, among others $\mathrm{PI}_{\mathrm{s} 10}$ - Hydrological flows

$\mathrm{PI}_{\mathrm{s} 11}$ - Water availability (surface and groundwater)

$\mathrm{PI}_{\mathrm{s} 12}$ - Noise levels (with and without defence activities, particularly exercises): (within the unit area and outside) $\mathrm{PI}_{\mathrm{s} 13}$ - Odour levels

$\mathrm{PI}_{\mathrm{s} 14}$-Environmental incident rate

$\mathrm{PI}_{\mathrm{s} 15}$-Endangered species of flora and fauna

$\mathrm{PI}_{\text {s16 }}$ - Breeding species

$\mathrm{PI}_{\mathrm{s} 17}$ - Plant and animal diversity

$\mathrm{PI}_{\mathrm{s} 18}$ - Habitat fragmentation

$\mathrm{PI}_{\mathrm{s} 19}$ - Protected areas and sensitive/critical habitats

$\mathrm{PI}_{\mathrm{s} 20}$ - Cultural and heritage sites, artefacts, and monuments

Impacts-effects

$\mathrm{PI}_{\mathrm{i} 1}$ - Health effects (staff and local communities)

$\mathrm{PI}_{\mathrm{i} 2}$ - Quality of life degradation

$\mathrm{PI}_{\mathrm{i} 3}$ - Noise impacts on population

$\mathrm{PI}_{\mathrm{i} 4}$-Cultural heritage degradation, including historic properties, archaeological sites, and more traditional cultural sites

$\mathrm{PI}_{\mathrm{i} 5}$ - Biotic communities disturbance

$\mathrm{PI}_{\mathrm{i}}$ - Effects on the quality of organisms used in human diet (e.g. marine organisms):

$\mathrm{PI}_{\mathrm{i} 7}$ - Area of habitats disturbed

$\mathrm{PI}_{\mathrm{i} 8}$-Visual impacts

Responses

$\mathrm{PI}_{\mathrm{r} 1}$ - Wastewater treatment

$\mathrm{PI}_{\mathrm{r} 2}-$ Water supply treatment

$\mathrm{PI}_{\mathrm{r} 3}$-Water recycled and reused (including wastewater or other used water (e.g. cooling water)

$\mathrm{PI}_{\mathrm{r} 4}$ - Buildings with a water conservation plan

$\mathrm{Ha}$

No year ${ }^{-1}$

No year ${ }^{-1}$

No. of vehicles

circulating ha ${ }^{-1}$ year $^{-1}$

Ha year $^{-1}$; no year ${ }^{-1}$

No. of contaminated sites; ha; $\mathrm{m}^{3}$

Ha; \%

Ha; \%;

$\mathrm{Ha} ; \%$

$\mathrm{Ha} ; \%$

$\mu \mathrm{g} \mathrm{m}^{-3}$; no. of days exceeding air quality standards year ${ }^{-1}$

$\mu \mathrm{g} \mathrm{m}^{-3}$; no. of days exceeding air quality standards year ${ }^{-1}$

Curie, Becquerel

$\mathrm{Mgl}^{-1} ; \%$ of non-compliance

samples year ${ }^{-1}$; MPN. $100 \mathrm{ml}^{-1}$ (for microbiological parameters)

$\mathrm{m}^{3} \mathrm{~s}^{-1}$

$\mathrm{Hm}^{3}$ year $^{-1}$

No. of sites exceeding noise levels limits year ${ }^{-1}$

"odour units" (OU) (which are

dimensionless)

No year ${ }^{-1}$

No. of species

No year $^{-1}$

No. of species

Qualitative assessment

Ha; no.

$\mathrm{Ha}$; no.; qualitative assessment

blood lead levels: ppm

Qualitative assessment

$\%$ of population highly annoyed

Qualitative assessment

Community disturbance assessments; number animals deaths.year ${ }^{-1}$

Presence of faecal contamination in bivalvia (MPN indicator of faecal contamination $\mathrm{FW}^{-1}$ )

$\%$; ha

Qualitative assessment

$\%$ population served by wastewater treatment plants

$\%$ population served by water

treatment

$\mathrm{m}^{3}$ year $^{-1} ; \%$
2

1

1

1 
Table A1 (continued)

\begin{tabular}{l}
\hline Indicators categories \\
\hline $\mathrm{PI}_{\mathrm{r}}$-Energy conservation measures (facilities with an energy \\
efficiency plan or completion of energy audit) \\
$\mathrm{PI}_{\mathrm{r} 6}$ - Renewable energy used \\
$\mathrm{PI}_{\mathrm{r} 7}$-Alternative fuel vehicles, purchased/leased (for tactica \\
and non-tactical vehicles) \\
$\mathrm{PI}_{\mathrm{r} 8}$ - Reduction of aviation fuel storage capacity \\
$\mathrm{PI}_{\mathrm{r} 9}$ - Noise planning (critical areas: airfields, helicopter \\
landing areas, small arms ranges and artillery ranges) $\mathrm{PI}_{\mathrm{r} 10}$-Disposal, treatment and recycling of wastes, in \\
particular hazardous wastes, military equipment and \\
ammunition wastes (disposal to landfill, incineration, \\
recycling, composting and energy from waste) \\
$\mathrm{PI}_{\mathrm{r} 11-\text { Reuse of military uniforms }}$ \\
$\mathrm{PI}_{\mathrm{r} 12}$ - High-risk hazardous materials eliminated from use \\
$\mathrm{PI}_{\mathrm{r} 13}$ - Hazardous materials/waste management plans \\
$\mathrm{PI}_{\mathrm{r} 14-\text { Personnel with environmental tasks (individual }}$ \\
equivalent to 100\% daily task time) \\
$\mathrm{PI}_{\mathrm{r} 15}$-Environmental training (at all organization levels)
\end{tabular}

$\mathrm{PI}_{\mathrm{r} 15}$-Environmental training (at all organization levels)

$\mathrm{PI}_{\mathrm{r} 16}$ - Person in charge of environmental issues

$\mathrm{PI}_{\mathrm{r} 17}$ Environmental awareness levels of the personnel

$\mathrm{PI}_{\mathrm{r} 18}$ - Environmental Management Systems (EMS) in place (EMAS and/or ISO 14001 registered EMS)

$\mathrm{PI}_{\mathrm{r} 19}$-Goals, objectives and targets reached

$\mathrm{PI}_{\mathrm{r} 20}$ - Initial environmental survey

$\mathrm{PI}_{\mathrm{r} 21}$-Environmental audits: voluntary (including self audits) and mandatory

$\mathrm{PI}_{\mathrm{r} 22}$-Environmental policy statement (EPS)

$\mathrm{PI}_{\mathrm{r} 23}$-Environmental programs in place

$\mathrm{PI}_{\mathrm{r} 24}$ - Environmental considerations in systems acquisition processes (e.g. new weapons systems)

$\mathrm{PI}_{\mathrm{r} 25}$-Environmental considerations in new weapons systems development

$\mathrm{PI}_{\mathrm{r} 26}$ - Suppliers/contractors with EMS implemented $\mathrm{PI}_{\mathrm{r} 27}$ Environmental reporting and communication on defence sector's environmental activity

$\mathrm{PI}_{\mathrm{r} 28}$ - Environmental monitoring programs

$\mathrm{PI}_{\mathrm{r} 29}$-Effective internal and external stakeholder relationships

$\mathrm{PI}_{\mathrm{r} 30}$-Environmental complaints from external stakeholders (e.g. local communities, NGOs)

$\mathrm{PI}_{\mathrm{r} 31}$ - Voluntary monitoring conducted by local community citizens, NGOs, among others

$\mathrm{PI}_{\mathrm{r} 32}$ - Cooperation with civilian society in environmental disasters

$\mathrm{PI}_{\mathrm{r} 33}$ - Outdoor environmental recreation activities for stakeholders

$\mathrm{PI}_{\mathrm{r} 34}$ - Recreational and leisure area for local communities

$\mathrm{PI}_{\mathrm{r} 35}$ - Environmental budgeting, costs (reactive and

proactive) and investments

$\mathrm{PI}_{\mathrm{r} 36}$ - Environmental considerations in military training

exercise programs

$\mathrm{PI}_{\mathrm{r} 37}$ - Training areas with environmental management plans

$$
\text { Units (examples) }{ }^{\mathrm{a}}
$$

No.; no. of new audits year ${ }^{-1} ; \%$

Score relevancy

Feasibility

$\mathrm{J}_{\text {year }}{ }^{-1} ; \%$

no year ${ }^{-1} ; \%$

3

2

No. of air vehicles.year ${ }^{-1}$

$\%$ of total critical areas; no. of new

plans year $^{-1}$;

$\%$; tyear $^{-1}$

3

1

2

3

1

3

2

$\%$

$\%$; t year $^{-1}$

No year ${ }^{-1}$

No year $^{-1}$

$\%$ of total number of staff; average hours of environmental instruction and training person ${ }^{-1}$ year $^{-1}$; no. of environmental education and awareness-raising initiatives.

No.

Qualitative assessment (poor, very poor, medium, good, very good); no. of environmental practices known by the staff

$\%$; no.

$\%$; no.

$\%$; no.

$\%$; no.

$\%$; no.

$\%$; no.

$\%$; no. of contracts with

environmental conditions

No. of process changes adopted; $\%$ of equipment with reusable parts $\%$; no year ${ }^{-1}$

No. of disclosures year ${ }^{-1}$; No. of environmental reports year ${ }^{-1}$; no. of environmental workshops year ${ }^{-1}$; no. of environmental and defence Internet sites

No. of programs 3

No. of positive and negative enquiries from stakeholders year ${ }^{-1}$; no. of meetings with stakeholders' representatives year ${ }^{-1}$

No year ${ }^{-1}$

No. of actions year ${ }^{-1}$

No. of cooperation cases year ${ }^{-1}$

No. of activities year ${ }^{-1}$

ha; no.

$10^{3} €_{\text {year }}{ }^{-1}$

Yes/no

1

1 3 
Table A1 (continued)

\begin{tabular}{|c|c|c|c|}
\hline Indicators categories & Units (examples) $^{\mathrm{a}}$ & Score relevancy & Feasibility \\
\hline $\begin{array}{l}\mathrm{PI}_{\mathrm{r} 38} \text {-Environmental missions/services (e.g. forest fire } \\
\text { prevention; marine pollution prevention and combat) }\end{array}$ & $\begin{array}{l}\text { No. of man-days year }{ }^{-1} ; \text { No. of } \\
\text { missions year }{ }^{-1} ; €\end{array}$ & 3 & 3 \\
\hline $\mathrm{PI}_{\mathrm{r} 39}-$ Military assistance to local authorities & $\begin{array}{l}\text { No. of man-days year }{ }^{-1} ; \text { No. of } \\
\text { actions year }{ }^{-1} ; €\end{array}$ & 3 & 3 \\
\hline $\mathrm{PI}_{\mathrm{r} 40}$-Defence sector environmental awards & no. & 2 & 3 \\
\hline $\begin{array}{l}\mathrm{PI}_{\mathrm{r} 41} \text {-Strategic environmental assessments of policies, plans } \\
\text { or programmes }\end{array}$ & $\% ;$ no year $^{-1}$ & 3 & 3 \\
\hline $\mathrm{PI}_{\mathrm{r} 42}$-Environmental impact assessment of projects & $\% ;$ no year $^{-1}$ & 3 & 3 \\
\hline $\mathrm{PI}_{\mathrm{r} 43}-$ Compliance with environmental laws and agreements & $\begin{array}{l}\% \text {; number of inspected facilities } \\
\text { found to be in compliance year }{ }^{-1}\end{array}$ & 3 & 1 \\
\hline $\mathrm{PI}_{\mathrm{r} 44}$-Environmental fines & No year ${ }^{-1}$ & 3 & 1 \\
\hline $\mathrm{PI}_{\mathrm{r} 45}$-Safety, health and welfare programs & No. & 3 & 2 \\
\hline $\begin{array}{l}\mathrm{PI}_{\mathrm{r} 46} \text { - Eligible new construction projects incorporating the } \\
\text { "green building" concept }\end{array}$ & $\%$; no year ${ }^{-1}$ & 2 & 1 \\
\hline $\begin{array}{l}\mathrm{PI}_{\mathrm{r} 47} \text { - Firing ranges with bullet "traps" (bullet traps have a } \\
\text { rubber medium that captures bullets and retains them, as well } \\
\text { as a filter system that eliminates airborne lead dust) }\end{array}$ & $\%$; no. & 3 & 2 \\
\hline $\begin{array}{l}\mathrm{PI}_{\mathrm{r} 48} \text { Staff reaching the organization using public/collective } \\
\text { transport }\end{array}$ & $\%$ & 2 & 1 \\
\hline $\begin{array}{l}\mathrm{PI}_{\mathrm{r} 49}-\text { Construction and demolition projects with } \\
\text { environmental monitoring plans }\end{array}$ & $\%$; no. & 2 & 2 \\
\hline $\begin{array}{l}\mathrm{PI}_{\mathrm{r} 50}-\text { Management plans or protection measures for cultural } \\
\text { and heritage sites, artefacts, and monuments }\end{array}$ & $\%$; no. & 3 & 3 \\
\hline $\mathrm{PI}_{\mathrm{r} 51}-$ Military installations with decommissioning plan & $\begin{array}{l}\text { No.; } \% \text { of the total abandoned or } \\
\text { old facilities }\end{array}$ & 2 & 2 \\
\hline $\mathrm{PI}_{\mathrm{r} 52}-$ Revegetation areas & Ha.year $^{-1}$ & 3 & 2 \\
\hline $\mathrm{PI}_{\mathrm{r} 53}-$ Reuse of remediated contaminated sites & Ha year $^{-1}$; no year ${ }^{-1}$ & 2 & 2 \\
\hline $\begin{array}{l}\mathrm{PI}_{\mathrm{r} 54} \text {-Emergency response plans (fires, explosions, natural } \\
\text { disasters) }\end{array}$ & $\%$; no. & 2 & 3 \\
\hline \multicolumn{4}{|l|}{ Meta-performance } \\
\hline $\begin{array}{l}\mathrm{PI}_{\mathrm{m} 1} \text {-Sector-process changes adopted due to performance } \\
\text { results }\end{array}$ & $\%$; no.defence mission $^{-1}$ & 2 & 1 \\
\hline $\begin{array}{l}\mathrm{PI}_{\mathrm{m} 2}-\text { Identification of unexpected environmental aspects } \\
\text { and impacts }\end{array}$ & $\%$; no year ${ }^{-1}$ & 3 & 2 \\
\hline $\mathrm{PI}_{\mathrm{m} 3}-$ Effectiveness of mitigation and management measures & $\begin{array}{l}\% \text {; no. of mitigation measures } \\
\text { redesigned }\end{array}$ & 3 & 2 \\
\hline $\mathrm{PI}_{\mathrm{m} 4}$-Average cost of environmental performance indicators & $10^{3} €$ indicator $^{-1}$ year $^{-1}$ & 3 & 2 \\
\hline $\begin{array}{l}\mathrm{PI}_{\mathrm{m} 5} \text {-Environmental performance evaluation investments } \\
\text { and expenses }\end{array}$ & $10^{3} €$ year $^{-1}$ & 3 & 2 \\
\hline $\begin{array}{l}\mathrm{PI}_{\mathrm{m} 6} \text {-Institutional cooperation with other monitoring } \\
\text { activities (e.g. monitoring programs managed by Ministry of } \\
\text { the Environment) }\end{array}$ & No. & 3 & 3 \\
\hline $\begin{array}{l}\mathrm{PI}_{\mathrm{m} 7} \text {-Performance indicator results used to validate impact } \\
\text { prediction methods }\end{array}$ & $\begin{array}{l}\text { No. of predictions methods } \\
\text { validated }\end{array}$ & 2 & 1 \\
\hline $\begin{array}{l}\mathrm{PI}_{\mathrm{m} 8} \text { - Implementation of new environmental practices on the } \\
\text { basis of performance results }\end{array}$ & No year $^{-1}$ & 3 & 2 \\
\hline $\mathrm{PI}_{\mathrm{m} 9}$-Environmental indicator initiatives in defence units & No. & 3 & 2 \\
\hline $\begin{array}{l}\mathrm{PI}_{\mathrm{m} 10} \text {-Environmental staff with performance measuring as a } \\
\text { daily task (individual equivalent to } 100 \% \text { daily task time) }\end{array}$ & No. & 3 & 2 \\
\hline $\begin{array}{l}\mathrm{PI}_{\mathrm{m} 11} \text { - Stakeholders' feedback to environmental } \\
\text { performance information }\end{array}$ & $\begin{array}{l}\text { No year }{ }^{-1} \text { of messages received by } \\
\text { mail, letters or personal contacts }\end{array}$ & 3 & 2 \\
\hline $\mathrm{PI}_{\mathrm{m} 12}-$ Chemical use in indicator data collecting activities & $\begin{array}{l}\text { Loads of monitoring reagents } \\
\text { reaching environment: year }{ }^{-1}\end{array}$ & 2 & 1 \\
\hline $\begin{array}{l}\mathrm{PI}_{\mathrm{m} 13} \text { - Use of environmentally preferable products and } \\
\text { equipment in performance evaluation activities }\end{array}$ & $\begin{array}{l}\text { No. of environmentally preferable } \\
\text { products. Performance } \\
\text { activity }^{-1} \text { year }^{-1}\end{array}$ & 2 & 2 \\
\hline $\mathrm{PI}_{\mathrm{m} 14}$-Analytical measurements and related detection levels & $\begin{array}{l}\text { No year }{ }^{-1} \text { of indicator } \\
\text { measurements under analytical } \\
\text { detection level }\end{array}$ & 2 & 1 \\
\hline $\mathrm{PI}_{\mathrm{m} 15}-$ Revisions of indicators & no. of revisions year ${ }^{-1}$ & 3 & 3 \\
\hline
\end{tabular}

${ }^{\mathrm{a}}$ For each indicator unit of measurement presented, the appropriate normalizing factors (functional unit; members of staff (number); building area (ha); military units (number); public environmental investments and expenses (euros)) should be chosen. 


\section{References}

Arts, J., Caldwell, P., Taché, M., 2000. Environmental impact assessment follow-up: good practice and future directions. In: Proceedings of the 20th Annual IAIA Conference, International Association for Impact Assessment (IAIA), Hong-Kong.

Australian Department of Defence (Australian DoD), 2002. Environmental performance reporting framework (EPRF). (www page). URL: http://www.defence.gov.au/environment/pages/eprf.htm

Azzone, G., Manzini, R., Noci, G., Welford, R., Young, C.W., 1996. Defining environmental performance indicators: an integrated framework. Business Strategy and the Environment 5, 69-80.

Barber, M.C., 1994. Environmental monitoring and assessment program: indicator development strategy. US Environmental Protection Agency, Office of Research and Development, Environment Research Laboratory, Athens, EPA/620/R-94/022.

Bennett, M., James, P., 1999a. ISO 14031 and the future of environmental performance evaluation. In: Bennett, M., James, P., Klinkers, L. (Eds.), Sustainable Measures-Evaluation and Reporting of Environmental and Social Performance. Greenleaf Publishing, Sheffield, UK, pp. 76-97.

Bennett, M., James, P., 1999b. Key themes in environmental, social and sustainability performance evaluation and reporting. In: Bennett, M., James, P., Klinkers, L. (Eds.), Sustainable Measures-Evaluation and Reporting of Environmental and Social Performance. Greenleaf Publishing, Sheffield, UK, pp. 29-74.

Berkhout, F., Hertin, J., Azzone, G., Carlens, J., Drunen, M., Jasch, C., Noci, G., Olsthoorn, X., Tyteca, D., Woerd, F.V.D., Wagner, M., Wehrmeyer, W., Wolf, O., 2001. Measuring the Environmental Performance of Industry (MEPI). Final Report. EC Environmental and Climate Research Programme: Research Theme 4, Human Dimensions of Environmental Change, Contract No. ENV4-CT970655. SPRU—Science and Technology Policy Research, University of Sussex, Department of Economics and Production, Politecnico di Milano,; Institut für Oekologische Wirtschaftsforschung (IOeW), Institute for Environmental Studies, Vrije Universiteit Amsterdam, Centre Entreprise-Environnement (CEE), Université Catholique de Louvain; Centre for Environmental Strategy (CES), University of Surrey, IPTS Institute for Prospective Technological Studies, Brighton.

Boland, T., Fowler, A., 2000. A systems perspective of performance management in public sector organisations. The International Journal of Public Sector Management 13, 417-446.

Callens, I., Tyteca, D., 1995. Towards indicators of sustainable development for firms - concepts and definitions, draft. Université Catholique de Louvain, Institut d'Administration et de Gestion, Louvain, Belgium.

Characklis, G.W., Richards, D.J., 1999. The evolution of industrial environmental performance metrics: trends and challenges. Corporate Environmental Strategy 6, 387-398.

Carter, N., Klein, R., Day, P., 1992. How Organizations Measure Success: The Use of Performance Indicators in Government. Routledge, London.

Commission of the European Communities, 1999. Report on environment and integration indicators to Helsinki Summit. Commission Working Document. Brussels, Commission of the European Communities SEC (1999) 1942 final.

Commission of the European Communities, 2003. Communication from the Commission-Structural Indicators. Brussels, Commission of the European Communities COM(2003) 585 final.

Department of National Defence and the Canadian Forces (DND/CF), 1997. Environmentally sustainable defence activities: a sustainable development strategy for national defence. Department of National Defence and the Canadian Forces, Canada.

Department of National Defence and the Canadian Forces (DND/CF), 2000a. Environmentally sustainable defence activities: a sustainable development strategy for national defence. Department of National Defence and the Canadian Forces, Canada.
Department of National Defence and the Canadian Forces (DND/CF), 2000b. Enhanced performance measurement framework. Department of National Defence and Canadian Forces, Canada.

Department of National Defence and the Canadian Forces (DND/CF), 2003. Environmentally sustainable defence activities: sustainable development strategy. Department of National Defence and Canadian Forces, Canada.

Dias-Sardinha, I., Reijnders, L., 2001. Environmental performance evaluation and sustainability performance evaluation of organizations: an evolutionary framework. Eco-Management and Auditing 8, 71-79.

Dias-Sardinha, I., Reijnders, L., Antunes, P., 2002. From environmental performance evaluation to eco-efficiency and sustainability balanced scorecards: a study of organizations operating in Portugal. Environmental Quality Management Winter 99, 61-64.

Ditz, D., Ranganathan, J., 1997. Measuring Up: Toward a Common Framework for Tracking Corporate Environmental Performance. World Resources Institute, Washington, DC.

Environment Canada, 1997. Sustainable Development Strategy 1997-2000. Summary Document. Canada, Environment Canada.

Epstein, M.J., Young, S.D., 1998. Improving environmental performance through economic value added. Environmental Quality Management, pp. 1-7 (Summer).

European Environment Agency (EEA), 1999. Making sustainability accountable: eco-efficiency, resource productivity and innovation. European Environment Agency, Copenhagen.

European Environment Agency (EEA), 2000a. Are we moving in the right direction? Indicators on transport and environment integration in the EU. TERM 2000. European Environment Agency, Environmental issues series No. 12, Copenhagen.

European Environment Agency (EEA), 2000b. Common Framework for Sector-Environment Integration Indicators. European Environment Agency, Copenhagen.

European Environment Agency (EEA). (n.d.) Towards a European Menu of Environment Headline Indicators - a EEA proposal. European Environment Agency, Copenhagen.

European Parliament and the Council of the European Union, 2001. Regulation (EC) No. 761/2001 of the European Parliament and of the Council of 19 March 2001 allowing voluntary participation by organisations in a Community eco-management and audit scheme (EMAS). Official Journal L 114, p. 1 (24 April 2001).

Flynn, N., 2002. Public Sector Management. Pearson Education, Harlow, England.

Global Reporting Initiative (GRI), 2002. Sustainability reporting guidelines. Global Reporting Initiative, Boston: USA.

Government of Canada, 2000. Sustainable development in government operations: a coordinated approach. Ministry of Public Works and Government Services Canada, Canada.

Government of Canada, 2002. Greening Government: Your Guide to Greening Government Operations. Government of Canada, Canada.

Her Majesty's Stationery Office (HMSO), 1996. Indicators of sustainable development for the United Kingdom. HMSO Publications Centre, Indicators Working Group, Environmental Protection and Statistics and Information Management Division, Department of the Environment, London.

Hertin, J., Berkhout, F., Moll, S., Schepelmann, P., 2001. Indicators for monitoring integration of environment and sustainable development in enterprise policy. Final Report, Sussex, Science and Technology Policy Research (SPRU), University of Sussex.

Hodge, T., 1997. Toward a conceptual framework for assessing progress toward sustainability. Social Indicators Research 40, 5-98.

International Organisation for Standardization (ISO), 1996. International Standard ISO 14001: Environmental Management Systems-Specification with Guidance for Use. International Organisation for Standardization, Geneva.

International Organisation for Standardization (ISO), 2004. International Standard ISO 14001: Environmental Management Systems-Requirements with Guidance for Use. International Organisation for Standardization, Geneva. 
International Organisation for Standardization (ISO), 1999. International Standard ISO 14031: Environmental management: environmental performance evaluation: guidelines. International Organisation for Standardization. ISO 14031:1999(E), Geneva.

Johnson, S., 1998. Identification and selection of environmental performance indicators: application of the balanced scorecard approach. Corporate Environmental Strategy 5, 35-41.

Johnston, A., Smith, A., 2001. The characteristics and features of corporate environmental performance indicators: a case study of the water industry of England and Wales. Eco-Management and Auditing 8, 1-11.

Kaplan, R.S., Norton, D.P., 1996. The Balanced Scorecard: Translating Strategy into Action. Harvard Business School Press, Boston, MA.

Kuhre, W.L., 1998. ISO 14031: Environmental Performance Evaluation (EPE). Prentice-Hall, Inc., New Jersey.

Marine Corps Base - Camp Lejeune, 2002. Strategic plan-Marine corps base Camp Lejeune. Camp Lejeune, US Marine Corps Base.

Marshall, G., n.d. Indicators of sustainable development for the UK. Directorate of Defence Environmental Policy, UK Ministry of Defence (MOD), London.

Melo, J.J., Pegado, C., 2002. EcoBlock-A method for integrated environmental performance evaluation of companies and products (construction case-study). In: Proceedings of the Fifth International Conference on Eco-Balance, The Society of Non-traditional Technology, Tsukuba, Japan, pp. 399-402.

Ministério da Defesa Nacional (MDN), 2001. A protecção ambiental nas forças armadas. Lisboa, Ministério da Defesa Nacional, Despacho no. $77 / \mathrm{MDN} / 2001$.

Ministério da Defesa Nacional (MDN), 2002. Anuário estatístico da defesa nacional de 2001. Lisboa, Ministério da Defesa Nacional.

Mohninger, B., 1999a. Approaches for green procurement in the government of Jamaica (Draft). K1M 2B5 for the ENACT Programme, Ottawa, Canada.

Mohninger, B., 1999b. Approaches for solid waste management in the government of Jamaica (Draft). K1M 2B5, for the ENACT Programme, Ottawa, Canada.

Mohninger, B., 2000. Approaches for Water and Energy Conservation in the Government of Jamaica (Draft). Ottawa, Canada.

National Institute of Public Health and Environment (RIVM), 1995. A general strategy for integrated environmental assessment at the European Environment Agency. European Environment Agency, Copenhagen.

Netherlands Ministry of Defence (Netherlands MOD), 2000. Environmental performance indicators. The Netherlands Ministry of Defence, Netherlands.

North Atlantic Treaty Organisation (NATO), 2002. STANAG 7141 EP (Edition 1) (Ratification Draft 1) - Joint NATO doctrine for environmental protection during NATO led operations and exercises. North Atlantic Treaty Organisation, NATO Standardization Agency, Joint Service Board, NSA(JSB)0039-EP/7141, Brussels.

North Atlantic Treaty Organisation (NATO), 2000. Environmental Management Systems in the Military Sector: Final Report of the Pilot Study Group. Report No. 240. North Atlantic Treaty Organisation, Committee on the Challenges of Modern Society.

Olsthoorn, X., Tyteca, D., Wehrmeyer, W., Wagner, M., 2001. Environmental indicators for business: a review of the literature and standardisation methods. Journal of Cleaner Production 9, 453-463.

Organization for Economic Co-operation and Development (OECD), 1993a. Draft synthesis report: group on state of the environment workshops on indicators for use in environmental performance reviews. Organization for Economic Co-operation and Development, Doc ENV/EPOC/SE(96), Paris.

Organization for Economic Co-operation and Development (OECD), 1993b. OECD core set of indicators for environmental performance reviews. Paris, Organization for Economic Co-Operation and Development, OCDE/GD(93)179.

Organization for Economic Co-operation and Development (OECD), 1999. Indicators for the integration of environmental concerns into transport policies. Organisation for Economic Co-operation and Development, Working Group on the State of the Environment, ENV/EPOC//SE(98)1/Final.

Organization for Economic Co-operation and Development (OECD), 2001. 10 Indicators for the environment. Draft. Organization for Economic Co-operation and Development, Working Group on Environmental Information and Outlooks (WGEIO).

Ott, W.R., 1978. Environmental Indices-Theory and Practice. Ann Arbor Science, Michigan.

Personne, M., 1998. Contribution à la méthodologie d'intégration de l'environnement dans les PME-PMI: évaluation des performances environmentales. Thèse présentée pour obtenir le grade de docteur. Institut National des Sciences Appliquées de Lyon et l'Ecole Nationale Supérieur des Mines de Saint-Etienne, Lyon.

Ramos, T.B., 1996. Sistemas de indicadores e índices de qualidade da água e sedimento em zonas costeiras. Master's Thesis, Universidade de Aveiro, Aveiro: Portugal.

Ramos, T.B., Melo, J.J., 2005. Environmental management practice in the defence sector: assessment of the Portuguese military's environmental profile. Journal of Cleaner Production 13 (12), 1117-1130.

Ramos, T.B., Melo, J.J., 2006. Developing and implementing an environmental performance index for the Portuguese military. Business Strategy and the Environment 15 (2), 71-86.

Ramos, T.B., Alves, I., Subtil, R. and Melo, J.J., 2004a. Environmental aspects and impacts of public sector organizations: the Portuguese defence sector profile. In: Proceedings of the 2004 International Sustainable Development Research Conference. ERP Environment, University of Manchester: UK, (pp. 484-495).

Ramos, T.B., Alves, I., Subtil, R., Melo, J.J., 2004b. The state of environmental performance evaluation in the public sector: The profile of the Portuguese defence sector: Corporate Social Responsibility and Environmental Management Conference. ERP Environment, University of Nottingham, UK.

Ramos, T.B., Caeiro, S., Melo, J.J., 2004c. Environmental indicator frameworks to design and assess environmental monitoring programs. Impact Assessment and Project Appraisal 22, 47-62.

Ranganathan, J., 1998. Sustainability Rulers: Measuring Corporate Environmental \& Social Performance. World Resources Institute, Sustainable Enterprise Perspectives, Washington, DC.

South Africa Department of Defence (South Africa DoD), 2000. Environmental Implementation Plan, first ed. Department of Defence, Pretoria, South Africa.

Swedish Environmental Advisory Council (SOU), 1999. Green Headline Indicators-Monitoring Progress Towards Ecological Sustainability. Environmental Advisory Council, Stockolm: Swedish.

The Committee on Performance Measurement for Sustainable Government Operations (PMSGO), 1999. Environmental Performance Measures for Government Operations-A Guidance Document (version 1.0). Prepared by Marbek Resource Consultants for the Committee on Performance Measurement for Sustainable Government Operations (PMSGO), Canada.

Tyteca, D., Carlens, J., Berkhout, F., Hertin, J., Wehrmeyer, W., Wagner, M., 2002. Corporate environmental performance evaluation: evidence from the MEPI project. Business Strategy and the Environment 11, $1-13$.

Tyteca, D., 1996. On the measurement of the environmental performance of firms - A literature review and a productive efficiency perspective. Journal of Environmental Management 46, 281-308.

United Kingdom Government, 1997. The Greening Government Initiative 1997-98. UK Government, HC517, UK.

United Kingdom Government, 2002. Sustainable development in government. First Annual Report. Ministerial Sub-Committee of Green Ministers, $\operatorname{ENV}(\mathrm{G}), \mathrm{UK}$.

United Kingdom Ministry of Defence (UK MOD), 2002. Defence Environment and Safety Report. Annual Report to the Defence Environment and Safety Board 2001/02. Ministry of Defence, UK.

United Kingdom Ministry of Defence (UK MOD), 2003. Framework for Sustainable Development on the Government Estate: Ministry 
of Defence Sustainable Development Strategy. Ministry of Defence, . UK.

United Nations Environment Programme and National Institute of Public Health and the Environment (UNEP/RIVM), 1994. An Overview of Environmental Indicators: State of the Art and Perspectives. Nairobi, UNEP/EATR.94-01; RIVM/402001001.

United States Army (US Army), n.d. Army environmental management system (EMS) implementation metrics. US Army Office of the Assistant Secretary of the Army, Washington, DC.

United States Department of Defense (US DoD), 1999. Environmental Performance Indicators. Department of Defense, Washington, DC.

United States Department of Defense (US DoD), 2001. Revising Pollution Prevention \& Compliance Metrics. Department of Defense, Washington, DC.

United States Department of Defense (US DoD), 2003. Environmental Management System (EMS) Implementation Criteria and Metrics. Department of Defense, Washington, DC.

United States Department of Defense (US DoD), n.d. Environmental Performance Indicators. Department of Defense, Washington, DC.

United States Environmental Protection Agency (USEPA), 1995. A Conceptual Framework to Support Development and Use of Environmental Information in Decision Making. Environmental Protection Agency, Office of Policy and Planning and Evaluation, Washington, DC.
United States Environmental Protection Agency (USEPA), 1996. Federal Facilities Sector Notebook: A Profile of Federal Facilities. US Environmental Protection Agency, Office of Enforcement \& Compliance Assurance, Washington, DC, EPA 300-B-96-003.

United States Environmental Protection Agency (USEPA), 1999. Indicators of the Environmental Impacts of Transportation. Environmental Protection Agency, Washington, DC.

Wehrmeyer, W., Tyteca, D. and Wagner, M., 2001 How many (and which) indicators are necessary to compare the environmental performance of companies? A sectoral and statistical answer. In: Proceedings of Seventh European Roundtable on Cleaner Production. University of Lund, International Institute for Industrial Environmental Economics (IIIEE), Lund.

Welford, R., Young, W., Ytterhus, B., 1998. Towards sustainable production and consumption: a literature review and conceptual framework for the service sector. Eco-Management and Auditing 5, $38-56$.

Young, C.W., 1996. Measuring environmental performance. In: Welford, R. (Ed.), Corporate Environmental Management: Systems and Strategies. Earthscan, London, pp. 148-174.

Young, C.W., Welford, R.J., 1998. An environmental performance measurement framework for business. Greener Management International 21, 30-49. 